\title{
Involvement of Muscarinic Receptors in Hypotensive and Diuretic Effects of Aqueous Soluble Fraction from Asphodelus tenuifolius Cav.
}

\author{
Waqas Younis, ${ }^{1,2}$ Alamgeer, ${ }^{3}$ V. B. Schini-Kerth, ${ }^{4}$ Samara Requena Nocchi, ${ }^{5}$ \\ Denise Brentan Silva, ${ }^{5}$ Priscila de Souza, ${ }^{6}$ Ishfaq Ali Bukhari, ${ }^{7}$ Fahim Vohra, ${ }^{8}$ Sibtain Afzal, \\ and Arquimedes Gasparotto Junior ${ }^{10}{ }^{10}$ \\ ${ }^{1}$ Laboratory of Cardiovascular Research and Integrative Pharmacology, College of Pharmacy, University of Sargodha, \\ Sargodha 40100, Pakistan \\ ${ }^{2}$ Faculty of Pharmacy, The University of Lahore, I-Km Defence Road, Lahore, Pakistan \\ ${ }^{3}$ Punjab University College of Pharmacy, University of the Punjab, Lahore 54000, Pakistan \\ ${ }^{4}$ UMR CNRS 7213, Laboratory of Biophotonics and Pharmacology, Faculty of Pharmacy, University of Strasbourg, Illkirch, \\ Strasbourg, France \\ ${ }^{5}$ Laboratory of Natural Products and Mass Spectrometry, Faculty of Pharmaceutical Sciences, Food and Nutrition, \\ Federal University of Mato Grosso do Sul, Campo Grande 79.070-900, MS, Brazil \\ ${ }^{6}$ Postgraduate Program in Pharmaceutical Sciences, University of Vale Do Itajaí, Itajaí, SC, Brazil \\ ${ }^{7}$ Department of Pharmacology, College of Medicine, King Saud University, Riyadh, Saudi Arabia \\ ${ }^{8}$ Department of Prosthetic Dental Sciences, College of Dentistry, King Saud University, Riyadh, Saudi Arabia \\ ${ }^{9}$ Immunology Research Center, College of Medicine, King Saud University, Riyadh, Saudi Arabia \\ ${ }^{10}$ Laboratory of Cardiovascular Pharmacology (LaFaC), Federal University of Grande Dourados (UFGD), P.O. Box 533, \\ Dourados 79.804-970, MS, Brazil
}

Correspondence should be addressed to Arquimedes Gasparotto Junior; arquimedesgasparotto@gmail.com

Received 8 October 2020; Revised 14 December 2020; Accepted 2 January 2021; Published 15 January 2021

Academic Editor: Teh Ley Kek

Copyright (C) 2021 Waqas Younis et al. This is an open access article distributed under the Creative Commons Attribution License, which permits unrestricted use, distribution, and reproduction in any medium, provided the original work is properly cited.

Background. Asphodelus tenuifolius Cav. (Asphodelaceae) is widely used in Pakistan traditional medicine as a hypotensive and diuretic agent. Despite the cardioprotective effects described for A. tenuifolius, the mechanisms involved in its probable hypotensive and diuretic effects have never been evaluated. Firstly, different extracts from A. tenuifolius seeds were obtained, and their antioxidant profiles and chemical constituents by LC-DAD-were determined, including molecular networking by the GNPS platform. Then, to evaluate changes in blood pressure, different groups of anesthetized normotensive rats were intravenously treated with the crude extract (AT-Cr, 1-50 mg/kg), aqueous (AS-AT, 1-25 mg/kg), n-butanol (BS-AT, 1-50 mg/kg), and dichloromethane fraction (DS-AT, 1-80 mg/kg). The diuretic effects of AT-Cr, AS-AT, BS-AT, and DS-AT at 100, 200, and $300 \mathrm{mg} / \mathrm{kg}$, p.o. doses, were also evaluated in comparison with hydrochlorothiazide (HCTZ, $10 \mathrm{mg} / \mathrm{kg}$, p.o). The urinary volume, sodium, potassium, and $\mathrm{pH}$ were estimated in the sample collected for $6 \mathrm{~h}$ from saline-loaded rats. Using pharmacological antagonists or inhibitors, we determine the involvement of acetylcholine, prostaglandins, and nitric oxide in A. tenuifolius-induced hypotensive and diuresis action. In addition, the activities of angiotensinconverting enzyme, erythrocyte carbonic anhydrase, and renal $\mathrm{Na}+/ \mathrm{K}+/ \mathrm{ATPase}$ were evaluated in vitro. Acute treatment with crude extract and fractions of $A$. tenuifolius exhibited significant hypotensive and diuretic potential in normotensive rats. However, AS-AT produced the most potent and significant dose-dependent hypotension and diuretic effects in normotensive rats. Previous treatment with atropine significantly reduced the hypotensive and diuretic action of AS-AT, but pretreatment with indomethacin or L-NAME did not affect these effects. Moreover, the 7-day treatment with AS-AT did not reduce activities of serum angiotensin-converting enzyme, erythrocyte carbonic anhydrase, and renal $\mathrm{Na}+/ \mathrm{K}+/ \mathrm{ATPase}$. AS-AT showed four major compound node clusters, which included sugars, alkaloids, nucleoside, amino acid, and glycosylated flavonoids. This research supports and extends the traditional use of $A$. tenuifolius as a hypotensive and diuretic agent. The results showed that AS-AT from A. tenuifolius could present compounds responsible for hypotensive and diuretic activities through the activation of muscarinic receptors. 


\section{Introduction}

Cardiovascular disorders (CVDs) are continuously increasing in patients with renal insufficiency leading to their high disease and death rates [1]. Several problems in kidney functions become prerequisites for hypertension. $70-80 \%$ of chronic kidney disease (CKD) patients also have hypertension because problems in tubular reabsorption of sodium and water in chronic kidney diseases may lead to fluid accumulation and hypertension [2,3]. High salt intake increases the vascular tone and suppresses nitric oxide release. Besides that, high sodium levels also augment the potential effects of angiotensin II and norepinephrine [4].

In cardiovascular complication, diuretic agents as loop diuretics, thiazide, and potassium-sparing diuretics are commonly considered to mitigate the exacerbation related to congestion and edema. Diuretics today are a well-reputed medication for the reduction of blood volume and venous pressure to treat essential hypertension and heart failure. In addition to their beneficial role in hypertension, diuretics also improve mortality associated with chronic kidney disease, pulmonary edema, stroke, and congestive heart failure [5]. Meanwhile, pharmacovigilance clinical data also assure that diuretics are commonly related to a variety of adverse effects, such as alteration in systemic electrolyte balance, hypovolemia, metabolic alkalosis or acidosis, and hyperuricemia [6]. So, in the era of modern medicine, it is necessary to design and develop new diuretic agents that not only improve the therapeutic outcome in cardiovascular morbidities but may also overcome the undesired effects and events.

Recently, the bulk of studies reported on the pharmacological potential to explore and introduce new diuretic agents from natural products. These reports are mostly based on the empirical utilization of these herbs [7]. In Pakistan, a variety of herbal medicines are considered and traditionally being used as a diuretic, but an important need is to establish their folkloric claim on behalf of modern medicines.

Asphodelus tenuifolius Cav. (Asphodelaceae) is an annual, wild, herbaceous species locally named as bhokal, piazi, asphodel, and onion-like weed [8]. It is mostly observed in the Mediterranean area, North Africa, southern Europe, India, and Pakistan [9]. It is an edible plant generally considered as a cultivated vegetable [10]. A. tenuifolius seeds are majorly considered for the treatment of different cardiovascular diseases such as hypertension and diabetes. Various ethnobotanical studies have reported that seeds are diuretic in nature and can be used as a part of condiment or spice for the treatment of hypertension $[8,11]$. Seeds are also recommended for irritable bowel and digestive complications including hemorrhoids. It is also considered for the treatment of rheumatic pain and other inflammatory joint problems [12-14]. Phytochemical analysis of different extracts after cold and hot extraction techniques has confirmed the presence of polyphenols, chromones, condensed tannins, anthocyanin, anthraquinones glycosides, and a variety of alkaloids. Moreover, various phytochemical studies have evidenced the presence of chlorogenic acid, caffeic acid, vanillin, apigenin, chrysoberyl, rutin, and luteolin $[9,15]$.

A previous research study from our laboratory has revealed that $A$. tenuifolius has beneficial effects in reducing blood pressure and vascular complication, as well as protective effects on insulin resistance, dyslipidemia, and oxidative stress in glucose-fed rats [15]. Moreover, A. tenuifolius has also been studied for antimicrobial, anti-inflammatory, antioxidant, diuretic, and lipoxygenase inhibitory activity $[9,10]$. Therefore, considering the traditional uses and previous evidence of the effectiveness of A. tenuifolius against cardiovascular diseases, the current research was carried out to investigate the molecular mechanisms involved in the possible diuretic effect of A. tenuifolius and verify its relationship with a potential hypotensive effect using normotensive rats.

\section{Materials and Methods}

2.1. Chemicals and Drugs. Methanol, n-hexane, dichloromethane, ethyl acetate, n-butanol, hydrochlorothiazide (HCTZ), acetazolamide (ACTZ), N- $\omega$-Nitro-L-arginine methyl ester (L-NAME), indomethacin, atropine, ouabain octahydrate, hexamethonium bromide, captopril, and propranolol were purchased locally from Sigma-Aldrich Chemicals. Acetonitrile and formic acid were obtained from J. T. Baker. All these chemicals were of standard analytical grade.

2.2. Animals. Sprague-Dawley rats $(220-250 \mathrm{~g})$ from the central vivarium of the University of Sargodha were used in this study. All animals were maintained in controlled conditions ( $12 \mathrm{~h} \mathrm{light/dark} \mathrm{cycle,} 25 \pm 1^{\circ} \mathrm{C}$ temperature) with feed and water ad libitum. Animals were provided with housing conditions following accepted principles for laboratory animal use and care (NIH publication number \# $85-23$, revised in 1985), and we try to minimize animal distress and the number of animals used. All experimental procedures were approved (No. IAEC/UOS/2016/46) by the Ethical Committee of College of Pharmacy, University of Sargodha.

2.3. Extraction and Fractionation of Plant Material. The seeds of A. tenuifolius were purchased from a local herbal market in Lahore, Pakistan. Seeds were identified and authenticated by a plant taxonomist Dr. Amin-Ullah Shah, and a voucher specimen (\#W-6031) was submitted for further research reference at the Herbarium of the University of Sargodha. A. tenuifolius seeds $(4 \mathrm{~kg})$ were shade dried and pulverized to a coarse constituency for extraction. The powder was soaked in $3 \mathrm{~L}$ water and methanol $(30: 70, \mathrm{v} / \mathrm{v})$, followed by filtration with a muslin cloth and filter papers. This process was repeated three times, and the filtrate was concentrated by using a rotary evaporator and stored in a cool place $\left(4-6^{\circ} \mathrm{C}\right)$. The percentage yield of this crude extract of A. tenuifolius (AT-Cr) was $11 \%$. For activity guided 
fractionation, $100 \mathrm{~g}$ AT-Cr was mixed with distilled water, and liquid-liquid extractions were performed using solvents with different polarity based absolute solvents: hexane, dichloromethane, ethyl acetate, and n-butanol. Obtained fractions were concentrated at $40^{\circ} \mathrm{C}$ using a rotary evaporator. This process resulted in $26.4 \mathrm{~g}$ of the hexane fraction (HS-AT), $7 \mathrm{~g}$ of the dichloromethane fraction (DS-AT), $22.4 \mathrm{~g}$ of the butanol fraction (BS-AT), and $43 \mathrm{~g}$ of the aqueous soluble fraction (AS-AT). The ethyl acetate fraction was obtained in negligible quantities. The hexane soluble fraction was not used because it is insoluble in employed solvents. All these samples were placed at $4^{\circ} \mathrm{C}$ in a refrigerator for further pharmacological and phytochemical studies [16].

\subsection{Identification of Constituents by LC-DAD-MS Analysis} and Molecular Networking. Previously, the samples DS-AT, BS-AT, and AS-AT were analyzed by LC-DAD-MS, and here, they were reanalyzed to perform annotation by GNPS and to create the molecular network. A UFLC Prominence Shimadzu coupled to diode array detector (DAD) and a mass spectrometer MicrOTOF-Q III (Bruker Daltonics, Billerica, MA, USA) was used. The analyses were performed by a Kinetex C18 column $(2.6 \mu \mathrm{m}, 150 \times 2.1 \mathrm{~mm}$, Phenomenex $)$ applying the flow rate of $0.3 \mathrm{~mL} / \mathrm{min}$ and oven temperature of $50^{\circ} \mathrm{C}$. Ultrapure water (solvent A) and acetonitrile (solvent B), both added to $0.1 \%$ formic acid ( $\mathrm{v} / \mathrm{v})$, were used as mobile phase. The applied methods were the same described by Tolouei et al. (2019) [17]. The samples were prepared at $4 \mathrm{mg} / \mathrm{mL}$, and $2 \mu \mathrm{L}$ was injected into the chromatography column.

The annotation of the chemical constituents was performed by comparison of spectral data (UV, MS, and MS/ MS) with published data, as well as by the GNPS platform (https://gnps.ucsd.edu/). To create the molecular network, six fragment ions were considered, and for precursor and fragment ions, the mass tolerances were considered up $0.02 \mathrm{Da}$ and $0.1 \mathrm{Da}$. The molecular network was based on edges with cosine scores of more than 0.7 and 6 ions [18]. The molecular network was visualized in software Cytoscape 3.8 .

2.5. Determination of Total Flavonoid/Phenolic Contents and Antioxidant Potential. For the determination of the total flavonoid contents (TFCs), total phenolic contents (TPC), and antioxidant potential, we utilized the methodology described by Younis et al. (2017) [15]. DPPH (1, 1-diphenyl2-picryl-hydrazyl) radical scavenging assay, nitric oxide scavenging assay, total reducing power (TRP), and total antioxidant capacity (TAC) assays were used to determine antioxidant characteristics of AT-Cr, AS-AT, BS-AT, and DS-AT.

2.6. Direct Measurement of Blood Pressure. The direct surgical method was employed for measuring BP in anesthetized normotensive rats using thiopental $(70-90 \mathrm{mg} / \mathrm{kg})$. The trachea was exposed and cannulated to improve respiration during the length of the experiment. Next jugular vein and carotid artery were exposed and cannulated using a polyethylene catheter (PE-50) for extract/drug administration and recording BP, respectively. A catheter inserted into the carotid artery was connected to the pressure transducer fixed with the PowerLab data acquisition system for recording BP (ADI Instruments; Castle Hill, Australia). Following surgery, animals were allowed to stabilize for 30 minutes prior to record BP [19].

\subsubsection{Hypotensive Dose-Response Relationship of A. tenuifolius} Extracts. Rats were separated into five groups $(n=6)$ : Group $\mathrm{I}=$ received $\mathrm{NaCl} 0.9 \%$, Group II $=$ AT $-\mathrm{Cr}(1-50 \mathrm{mg} / \mathrm{kg})$, Group III = BS-AT $\quad(1-50 \mathrm{mg} / \mathrm{kg}), \quad$ Group $\quad \mathrm{IV}=\mathrm{AS}-\mathrm{AT}$ $(1-25 \mathrm{mg} / \mathrm{kg})$, and Group V = DS-AT $(1-80 \mathrm{mg} / \mathrm{kg})$. Blood pressure and heart rate were estimated for 45 minutes after dosing. Freshly prepared dilutions of extract were administered to rats at $1 \mathrm{ml} / \mathrm{kg}$, and a dose of the most active fraction was selected which provided a $50 \%$ reduction in $\mathrm{BP}$ to further understand the blood pressure-lowering mechanism.

\subsubsection{Evaluation of Mechanisms Underlying the Hypotensive} Effect of A. tenuifolius. Normotensive rats were anesthetized using thiopental $(70-90 \mathrm{mg} / \mathrm{kg})$, and blood pressure was measured using the direct surgical method as described earlier. Different groups of rats were given hexamethonium bromide $(30 \mathrm{mg} / \mathrm{kg})$, atropine $(1 \mathrm{mg} / \mathrm{kg})$, captopril $(2.5 \mathrm{mg} /$ $\mathrm{kg})$, indomethacin $(5 \mathrm{mg} / \mathrm{kg})$, L-NAME $(20 \mathrm{mg} / \mathrm{kg})$, and propranolol $(100 \mathrm{mg} / \mathrm{kg}), 10 \mathrm{~min}$ prior to AS-AT $(25 \mathrm{mg} / \mathrm{kg}$, i.v) administration. Change in blood pressure was documented for $45 \mathrm{~min}$ postdosing [19].

2.7. Assessment of the Diuretic Effect. The method used by Kau et al. [20] was followed by a few modifications to access the diuretic activity of extract/fractions. Rats were divided into eleven groups $(n=5)$ for acute study and three groups $(n=5)$ for a 7-day prolonged study. Animals fastened for 12 hours before experiment with access to water ad libitum. Animals were acclimatized for one week by placing them in separate individual metabolic cages daily for environmental adaptation.

2.7.1. Acute Diuretic Activity. To assure uniform water and sodium load, saline $(0.9 \% \mathrm{NaCl})$ at $5 \mathrm{ml} / 100 \mathrm{gm}$ was given to the animals $45 \mathrm{~min}$ before extract administration. The control group was given vehicle (deionized water) and standard group $10 \mathrm{mg} / \mathrm{kg} \mathrm{HCTZ}$ while treatment groups were given 100, 200, and $300 \mathrm{mg} / \mathrm{kg}$ of AT-Cr, BS-AT, AS$\mathrm{AT}$, and DS-AT. Instantly after dosing, animals were kept in metabolic cages, and urine was collected and volume was recorded at 2, 4, and $6 \mathrm{~h}$. Cumulative urine excretion was calculated according to body weight as $\mathrm{mL} / 100 \mathrm{~g}$. At the end of the experiment, urine electrolyte concentration (sodium and potassium) was estimated and expressed as $\mathrm{mmol} / \mathrm{L}$; moreover, urine $\mathrm{pH}$ was also determined [21]. 
2.7.2. Prolonged Diuretic Activity. Overnight fasting animals were given AS-AT $(300 \mathrm{mg} / \mathrm{kg})$ for continuous 7 days. A urine sample was collected on the first and seventh days in a graduated cylinder for 6 hours. Urine volume, sodium, and potassium concentration were estimated. Blood was collected by cardiac puncture, and serum was obtained by centrifugation $\left(2000 \mathrm{rpm}, 10 \mathrm{mins}, 4^{\circ} \mathrm{C}\right)$ to measure the plasma concentration of sodium and potassium by an automated electrolyte analyzer [22].

2.7.3. Evaluation of Mechanism Involved in the Diuretic Activity of A. tenuifolius. (1) Role of the Nitric Oxide (NO), Prostaglandins, and Acetylcholine in the Diuretic Effect of A. tenuifolius. The procedure described earlier for acute activity was followed. Different groups of rats were given L-NAME (60 mg/kg), indomethacin $(5 \mathrm{mg} / \mathrm{kg})$, and atropine $(1 \mathrm{mg} / \mathrm{kg})$ p.o. $1 \mathrm{~h}$ prior to experiments, followed by administration of deionized water $(5 \mathrm{ml} / \mathrm{kg}$; p.o.) in the control group and $300 \mathrm{mg} / \mathrm{kg}$ AS-AT in the treated group. The urine was collected for $6 \mathrm{~h}$ after the treatments. Total urine output as well as urine sodium and potassium concentration was measured [22].

(2) Measurement of Angiotensin-Converting Enzyme (ACE) Activity in the Prolonged Diuretic Activity. For ACE activity, rats were separated into four groups $(n=5)$ and treated with AS-AT $(30,100$, and $300 \mathrm{mg} / \mathrm{kg})$ and captopril $(60 \mathrm{mg} / \mathrm{kg})$. Briefly, after seven days of treatment, blood was collected from overnight fasting treated animals and centrifuged, and serum was separated. Serum $(10 \mu \mathrm{L})$ was mixed with assay solution $(490 \mu \mathrm{L})$ and incubated for $15 \mathrm{~min}$ at $37^{\circ} \mathrm{C}$. Then $1.2 \mathrm{~mL}$ of $\mathrm{NaOH}$ was added to halt the reaction followed by the addition of $100 \mu \mathrm{L}$ of o-phthaldialdehyde. Finally, the formation of His-Leu in the reaction mixture was analyzed fluorometrically in triplicate to measure ACE activity.

(3) Measurement of Erythrocyte Carbonic Anhydrase Activity in the Prolonged Diuretic Activity. Rats were separated into four groups $(n=5)$ and treated with AS-AT (30, 100 , and $300 \mathrm{mg} / \mathrm{kg}$ ) and acetazolamide $(10 \mathrm{mg} / \mathrm{kg})$. Briefly, after 7 days, blood samples were collected, and red blood cells (RBCs) were isolated. $1 \mathrm{~mL}$ of RBCs was added to $3 \mathrm{~mL}$ of distilled water and $3 \mathrm{ml}$ of chloroform. This mixture was centrifuged for $10 \mathrm{~min}$ at $8000 \mathrm{~g}$ to obtain supernatant which was diluted in distilled water at the ratio of $1: 10(\mathrm{v} / \mathrm{v})$, forming a hemolysate at a dilution of $1 / 40(\mathrm{v} / \mathrm{v})$. Two samples of hemolysate $(50 \mu \mathrm{L})$ were incubated with $1 \mathrm{ml}$ of alpha-naphthyl acetate containing $2 \%$ dioxane. One sample was incubated at $37^{\circ} \mathrm{C}$ with $1 \mathrm{ml}$ acetazolamide for $20 \mathrm{~min}$ whereas, in the 2 nd sample, acetazolamide was added at the end of incubation followed by the addition of $500 \mu \mathrm{L}$ of 5 chloro-o-toluidine to both samples. The reaction mixture was kept for 15 minutes followed by measurement of absorbance at $555 \mathrm{~nm}$ in triplicate [23].

(4) In Vitro Determination of Renal $\mathrm{Na}^{+} / \mathrm{K}^{+} /$ATPase Activity. The $\mathrm{Na}+/ \mathrm{K}+/ \mathrm{ATP}$ ase activity was estimated by the methodology of Noel and Godfraind [24], with minor changes using kidney samples with increasing concentrations $(3-30 \mu \mathrm{M})$ of AS-AT. The assay solution $(0.5 \mathrm{ml})$ was incubated into the kidney samples for $2 \mathrm{hr}$ at $37^{\circ} \mathrm{C}$. Before incubation, proteins in the kidney were so adjusted so that only $10-15 \%$ of the substrate could be hydrolyzed. The specific activity of the $\mathrm{Na}+\mathrm{K}+/$ ATPase enzyme was measured by the difference in the ATPase activity in the absence and presence of $1 \mathrm{mM}$ ouabain (ouabain-resistant activity).

2.8. Statistical Analysis. The results were statistically analyzed by GraphPad prism 5.0 and presented as mean \pm standard error mean (SEM). One-way ANOVA and two-way ANOVA were applied as required followed by Dunnett's or Bonferroni's posttest whereas $P$ values less than 0.05 were considered as significant.

\section{Results}

3.1. Annotation and Molecular Networking of the Constituents from $A$. tenuifolius. The extract and fractions from A. tenuifolius were previously analyzed by LC-DAD-MS, and some constituents could be annotated [25]. Thus, we reanalyzed them to expand the annotation of the constituents using GNPS library and data reported in the literature (Figure 1, Table 1); moreover, the data were applied to create the molecular network from their constituents and so determine the goal compounds from the most active fraction AS-AT (Figure 2). The molecular formulae of the constituents from AS-AT were determined based on the mass errors up \pm 10 ppm and mSigma below 30 .

The peaks 1, 2, and 3 were previously described from A. tenuifolius [25], and they were putatively annotated as hexitol $\left(m / z 183.0861[\mathrm{M}+\mathrm{H}]^{+}, \mathrm{C}_{6} \mathrm{H}_{14} \mathrm{O}_{6}\right)$, di-O-hexoside $(\mathrm{m} / z$ $\left.365.1037[\mathrm{M}+\mathrm{Na}]^{+}, \mathrm{C}_{12} \mathrm{H}_{22} \mathrm{O}_{11}\right)$, and tri-O-hexoside $(\mathrm{m} / z$ $\left.527.1554[\mathrm{M}+\mathrm{Na}]^{+}, \mathrm{C}_{18} \mathrm{H}_{32} \mathrm{O}_{16}\right)$. The compounds 4 and 6 revealed protonated ions at $m / z 118.0863$ and 268.1056 relative to molecular formula $\mathrm{C}_{5} \mathrm{H}_{11} \mathrm{NO}_{2}$ and $\mathrm{C}_{10} \mathrm{H}_{13} \mathrm{~N}_{5} \mathrm{O}_{4}$. Their fragment ions $m / z 101$ and 136 were yielded from losses of $\mathrm{NH}_{3}$ $(17 u)$ and pentosyl group $(132 u)$. Thus, they were annotated as the amino acid valine (4) and the nucleoside adenosine (6) [26].

The peaks 8 and 9-10 revealed similar UV spectra $\left(\lambda_{\max } \approx 285 \mathrm{~nm}\right)$. The fragment ions at $m / z 171[\mathrm{M}+\mathrm{H}-$ $\left.\mathrm{H}_{2} \mathrm{O}\right]^{+}$from 8 and $m / z 351[\mathrm{M}+\mathrm{H} \text {-hexosyl }]^{+}$and 189 $[\mathrm{M}+\mathrm{H}-2 \times \text { hexosyl }]^{+}$from $\mathbf{9 / 1 0}$ were compatible with the observed for peganine and di-O-hexosyl pegamine, respectively $[27,28]$. In addition, the compounds 12-13, 15, and 17 exhibited similar UV spectra of flavonols $\left(\lambda_{\max }=265\right.$ and $355 \mathrm{~nm}$ ) and flavones $\left(\lambda_{\max } \approx 270\right.$ and $\left.340 \mathrm{~nm}\right)$ [29]. The precursor ions of 12, 13, and 17 revealed fragment ions yielded from subsequent losses of hexosyl groups (162 u), such as the ions $m / z 449[\mathrm{M}+\mathrm{H} \text {-hexosyl }]^{+}$and $287[\mathrm{M}+\mathrm{H}$ $2 \times$ hexosyl $]^{+}$from 13 . For flavonoid 17, an additional loss of $146 u(\mathrm{~m} / z 431 \longrightarrow 285)$ suggested the deoxyhexosyl substituent, and a loss of radical methyl $\left({ }^{\bullet} \mathrm{CH}_{3}, 15 u\right)$ from aglycone ion $(\mathrm{m} / z 285 \longrightarrow 270)$ suggested the aglycone $O$ methyl apigenin. The aglycone ions of 12 and 13 were observed at $m / z 303$ and 287, respectively. Thus, 12, 13, and 17 were annotated as tri- $O$-hexosyl quercetin, tri- $O$-hexosyl luteolin, and tri-O-hexosyl $O$-deoxyhexosyl $O$-methyl apigenin [30]. 




FIGURE 1: Base peak chromatogram (positive ion mode) from the aqueous soluble fraction of A. tenuifolius.

TABle 1: Constituents identified from aqueous soluble fraction from Asphodelus tenuifolius by LC-DAD-MS/MS.

\begin{tabular}{|c|c|c|c|c|c|c|}
\hline \multirow[b]{2}{*}{ Peak } & \multirow[b]{2}{*}{$\begin{array}{c}\mathrm{RT} \\
(\mathrm{min})\end{array}$} & \multirow[b]{2}{*}{ Compound } & \multirow[b]{2}{*}{$\begin{array}{l}\text { UV } \\
(\mathrm{nm})\end{array}$} & \multirow[b]{2}{*}{ MF } & \multicolumn{2}{|r|}{ Positive mode $(\mathrm{m} / \mathrm{z})$} \\
\hline & & & & & $\begin{array}{c}\mathrm{MS} \\
{[\mathrm{M}+\mathrm{H}]^{+}}\end{array}$ & MS/MS \\
\hline 1 & 1.1 & Hexitol & - & $\mathrm{C}_{6} \mathrm{H}_{14} \mathrm{O}_{6}$ & 183.0861 & 91 \\
\hline 2 & 1.2 & di-O-hexoside & - & $\mathrm{C}_{12} \mathrm{H}_{22} \mathrm{O}_{11}$ & $365.1037^{\mathrm{a}}$ & \\
\hline 3 & 1.3 & Tri-O-hexoside & - & $\mathrm{C}_{18} \mathrm{H}_{32} \mathrm{O}_{16}$ & $527.1554^{\mathrm{a}}$ & 365 \\
\hline 4 & 1.3 & Valine & - & $\mathrm{C}_{5} \mathrm{H}_{11} \mathrm{NO}_{2}$ & 118.0863 & 101 \\
\hline 5 & 1.4 & Unknown & - & $\mathrm{C}_{16} \mathrm{H}_{26} \mathrm{~N}_{2} \mathrm{O}_{11}$ & 423.1618 & $254,244,224,196$ \\
\hline 6 & 2.2 & Adenosine & 268 & $\mathrm{C}_{10} \mathrm{H}_{13} \mathrm{~N}_{5} \mathrm{O}_{4}$ & 268.1056 & 136,119 \\
\hline 7 & 2.8 & Unknown & - & $\mathrm{C}_{16} \mathrm{H}_{26} \mathrm{~N}_{2} \mathrm{O}_{10}$ & 407.1672 & $394,369,355,309,297,271,254$ \\
\hline 8 & 4.8 & Peganine (vasicine) & 285 & $\mathrm{C}_{11} \mathrm{H}_{12} \mathrm{~N}_{2} \mathrm{O}$ & 189.1028 & $171,143,118,140$ \\
\hline 9 & 5.0 & di-O-hexosyl pegamine & 280 & $\mathrm{C}_{23} \mathrm{H}_{32} \mathrm{~N}_{2} \mathrm{O}_{11}$ & 513.2060 & $351,189,118$ \\
\hline 10 & 7.0 & di-O-hexosyl pegamine & 280 & $\mathrm{C}_{23} \mathrm{H}_{32} \mathrm{~N}_{2} \mathrm{O}_{11}$ & 513.2067 & $351,189,118$ \\
\hline 11 & 7.9 & Unknown & - & $\mathrm{C}_{32} \mathrm{H}_{44} \mathrm{O}_{14}$ & 675.2612 & $607,417,351$ \\
\hline 12 & 11.7 & Tri-O-hexosyl quercetin & 265,355 & $\mathrm{C}_{33} \mathrm{H}_{40} \mathrm{O}_{22}$ & 789.2087 & 465,303 \\
\hline 13 & 11.9 & Tri-O-hexosyl luteolin & 265,342 & $\mathrm{C}_{33} \mathrm{H}_{40} \mathrm{O}_{21}$ & 773.2158 & 449,287 \\
\hline 14 & 13.3 & Unknown & & $\mathrm{C}_{16} \mathrm{H}_{23} \mathrm{NO}_{5}$ & 310.1659 & $251,207,175,147$ \\
\hline 15 & 14.7 & 6,8-Di-C-hexosyl apigenin & 280,332 & $\mathrm{C}_{27} \mathrm{H}_{30} \mathrm{O}_{15}$ & 595.1637 & $\begin{array}{c}505,475,433,403,379,355,337, \\
325\end{array}$ \\
\hline 16 & 15.0 & Unknown & - & $\mathrm{C}_{26} \mathrm{H}_{35} \mathrm{NO}_{9}$ & 506.2357 & $452,413,376,298,221$ \\
\hline 17 & 23.8 & $\begin{array}{c}\text { Tri-O-hexosyl } O \text {-deoxyhexosyl } O \text {-methyl } \\
\text { apigenin }\end{array}$ & 270,338 & $\mathrm{C}_{40} \mathrm{H}_{52} \mathrm{O}_{24}$ & 917.2947 & $447,285,270$ \\
\hline
\end{tabular}

RT: retention time; MF: molecular formula; ${ }^{\mathrm{a}}:[\mathrm{M}+\mathrm{Na}]^{+}$.

The flavone $\mathbf{1 5}$ revealed a similar fragmentation pathway of $C$-glycosylated flavonoid. So, fragment ions yielded from consecutive losses of 90 and $120 u$ suggested the $C$-hexosyl substituents, such as the ions at $\mathrm{m} / z 505$ $[\mathrm{M}+\mathrm{H}-90]^{+}, 475[\mathrm{M}+\mathrm{H}-120]^{+}$, and $355[\mathrm{M}+\mathrm{H}-120-$ $120]^{+}$. This compound was annotated as 6,8 -di-C-hexosyl apigenin [31].

The molecular network of the constituents from A. tenuifolius exhibited four major node spectral families (Figure 2). The connections (edges) of nodes were represented by lines with thickness relative to cosine score, and the color green in nodes is relative to ion intensities from the AS-AT sample. We can observe a node cluster family of glycosylated flavonoids, but only four flavonoids were observed in AS-AT. In addition, a node cluster was observed from alkaloids.

3.2. Total Phenolic (TPC), Flavonoid Contents (TFCs), and Antioxidant Potential of A. tenuifolius. Standard regression lines for gallic acid were used to measure total phenolic contents, whereas standard regression lines for quercetin were used to measure total flavonoid contents (Table 2). Phenolic contents in AT-Cr were found as
$256.64 \pm 4.82 \mu \mathrm{g}$ gallic acid equivalent $/ \mathrm{mg}$, whereas flavonoid contents in ATC-Cr were found as $137.20 \pm 2.37 \mu \mathrm{g}$ quercetin equivalent $/ \mathrm{mg}$. The maximum quantity of both polyphenols and flavonoids was found in a crude extract of A. tenuifolius as compared to fractions whereas the total reducing power was found almost equal to total antioxidant capacity in all the extract/fractions. Furthermore, AT-Cr also exhibited high TRP and TAC in comparison to other fractions. The \% scavenging ability of DPPH and nitric oxide (NO-) by extract/fractions of $A$. tenuifolius is presented in Table 2. The dose-dependent scavenging ability of DPPH and nitric oxide free radicals was observed with all the extract/fractions. Crude extract at the dose of $500 \mu \mathrm{g} / \mathrm{mL}$ showed a maximum of $75.55 \%$ inhibition of DPPH radical, whereas a maximum of $66.19 \%$ nitric oxide (NO-) free radical inhibition by AT-Cr was observed at IC50 $259.4 \pm 4.93 \mu \mathrm{g} / \mathrm{mL}$ as compared to ascorbic acid IC50 of $225.81 \pm 5.24 \mu \mathrm{g} / \mathrm{mL}$. Similar DPPH and NO scavenging activities were exhibited by fractions of $A$. tenuifolius. These results indicated that crude extract and fractions of $A$. tenuifolius have significant free radicals scavenging ability. 


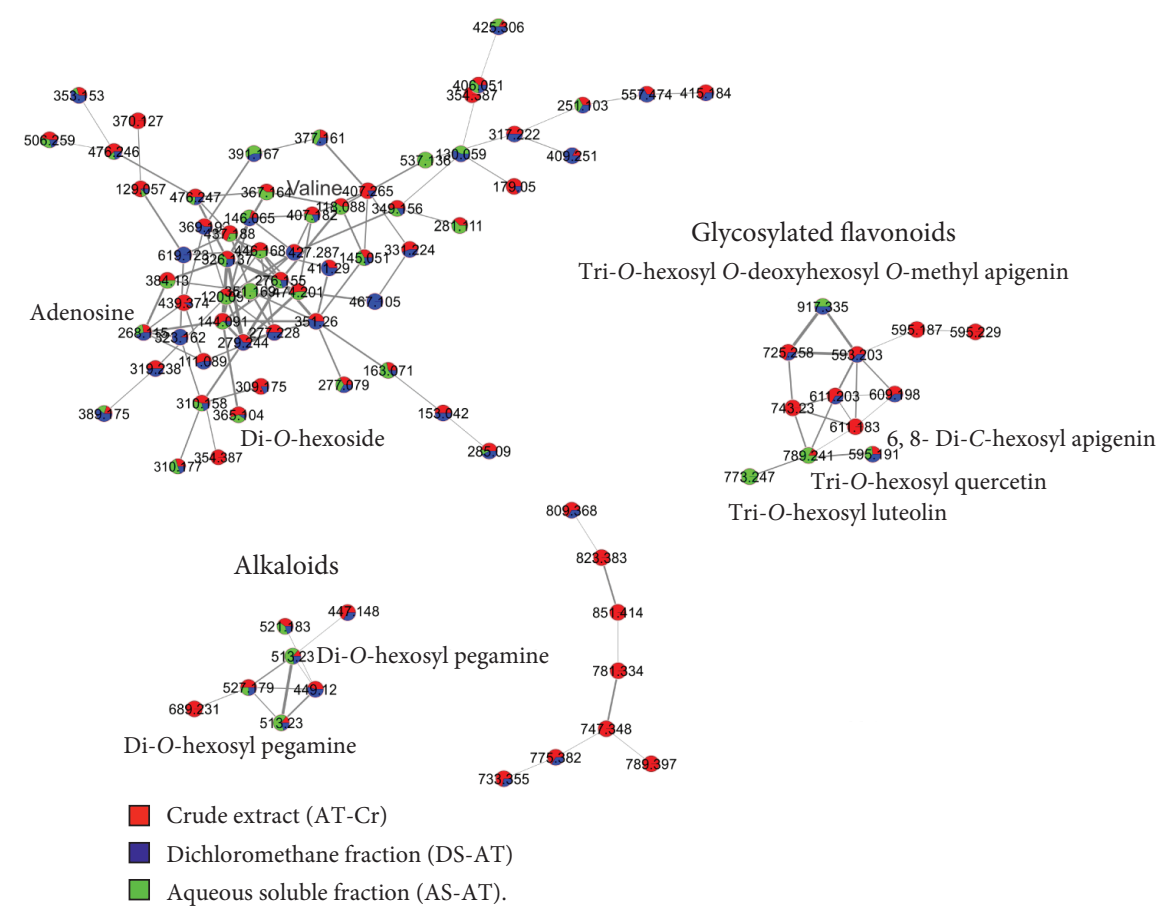

FIgUre 2: Molecular network from A. tenuifolius samples (AT-Cr, DS-AT, and AS-AT).

TABLe 2: Total phenolic and flavonoid contents, total antioxidant capacity, and total reducing power of A. tenuifolius.

\begin{tabular}{lcccccc}
\hline \multirow{2}{*}{ Sample } & TPC $(\mu \mathrm{g} \mathrm{GAE} / \mathrm{mg}$ & $\mathrm{TFC}(\mu \mathrm{g}$ QE/mg & TAC $(\mu \mathrm{g}$ AAE $/ \mathrm{mg}$ & TRP $(\mu \mathrm{g}$ GAE $/ \mathrm{mg}$ & DPPH scavenging & Nitric oxide Scavenging \\
& $\mathrm{DE}$ & $\mathrm{DE})$ & $\mathrm{DE})$ & $\mathrm{DE})$ & $\mathrm{IC} 50(\mu \mathrm{g} / \mathrm{ml})$ & $\mathrm{IC50}(\mu \mathrm{g} / \mathrm{ml})$ \\
\hline AT-Cr & $256.64 \pm 4.82$ & $137.20 \pm 2.37$ & $193.05 \pm 4.63$ & $185.46 \pm 3.77$ & $174.6 \pm 4.9$ & $255.8 \pm 6.9$ \\
$\mathrm{AS}-\mathrm{AT}$ & $190.51 \pm 7.5$ & $129.41 \pm 8.2$ & $176.85 \pm 11.2$ & $172.36 \pm 9.0$ & $274.8 \pm 7.30$ & $312.3 \pm 8.97$ \\
$\mathrm{BS}-\mathrm{AT}$ & $187.2 \pm 7.9$ & $112.7 \pm 6.3$ & $165.9 \pm 11.8$ & $151.2 \pm 8.7$ & $398.4 \pm 5.10$ & $353.2 \pm 11.4$ \\
DS-AT & $92.1 \pm 3.3$ & $78.5 \pm 6.2$ & $83.7 \pm 5.9$ & $79.2 \pm 8.3$ & $453.7 \pm 12.8$ & $551.5 \pm 13.8$ \\
AA & - & - & - & - & $12.86 \pm 2.10$ & $225.1 \pm 1.20$ \\
\hline
\end{tabular}

TPC: total phenolic contents; TFC: total flavonoid contents; TAC: total antioxidant capacity; TRP: total reducing power; GAE: gallic acid equivalent; QE: quercetin equivalent; AAE: ascorbic acid equivalent; DE: dry extract. Data values shown represent mean $\pm \operatorname{SEM}(n=3)$.

\subsection{Hypotensive Effect of A. tenuifolius and Its Mechanism of Action in Anesthetized Rats}

3.3.1. Acute Hypotensive Effect of A. tenuifolius Extracts/ Fractions in Normotensive Rats. After 30 minutes of stabilization, the average SBP of rats was recorded as $134.68 \pm 2.23 \mathrm{~mm}$, and no significant change was observed in blood pressure after the administration of normal saline (vehicle). The administration of crude extract and fractions of A. tenuifolius resulted in a significant and rapid reduction of SBP, DBP, and MBP (Figures 3 and 4), but no significant difference in heart rate was observed before and after extract/ fractions administration. The intravenous administration of AT-Cr $(1,10,20,30,40$, and $50 \mathrm{mg} / \mathrm{kg})$ produced a dosedependent decline in SBP which lasted for 48.12 \pm 3.65 , $58.14 \pm 2.94$, and $70.01 \pm 2.14 \mathrm{~mm} \mathrm{Hg}(30,40$, and $50 \mathrm{mg} / \mathrm{kg}$, respectively). Similarly, graded doses of BS-AT $(1,10,20,30$, 40 , and $50 \mathrm{mg} / \mathrm{kg}$ ) and DS-AT $(1,10,20,40,60$, and $80 \mathrm{mg} / \mathrm{kg})$ also produced a dose-dependent decline in SBP (Figure 3.33), which lasted for $66.21 \pm 4.19 \mathrm{~mm} \mathrm{Hg}$ decreases in SBP at $50 \mathrm{mg} / \mathrm{kg}$ of BS-AT, and $55.39 \pm 1.74 \mathrm{~mm} \mathrm{Hg}$ decreases in SBP at $80 \mathrm{mg} / \mathrm{kg}$ of for DS-AT. In contrast, intravenous administration of AS-AT $(1,5,10,15,20$, and $25 \mathrm{mg} / \mathrm{kg})$ caused a highly significant decline in SBP, DBP, and MBP, which lasted for the maximum decrease in SBP for $79.61 \pm 2.58 \mathrm{~mm} \mathrm{Hg}$ at the dose of $25 \mathrm{mg} / \mathrm{kg}$. Based on the most potent hypotensive action with AS-AT at $25 \mathrm{mg} / \mathrm{kg}$ dose, it was selected and further used for investigating the mechanism underlying its hypotensive effect.

3.3.2. AS-AT Produced Hypotensive Effect Mediated through Muscarinic Receptors. Pretreatment with atropine significantly prevented AS-AT-induced hypotensive effect in normotensive rats. However, propranolol, hexamethonium, L-NAME, indomethacin, and captopril did not change the hypotensive effect of AS-AT. Treatment with only AS-AT $(25 \mathrm{mg} / \mathrm{kg})$ causes a $65.27 \mathrm{mmHg}$ decrease in SBP whereas pretreatment with atropine significantly reduced this decrease in SBP to only $2.4 \mathrm{~mm} \mathrm{Hg}$ (Figure 5). These findings suggested that the hypotensive effect of ASAT could be mediated by muscarinic receptors. 




(a)

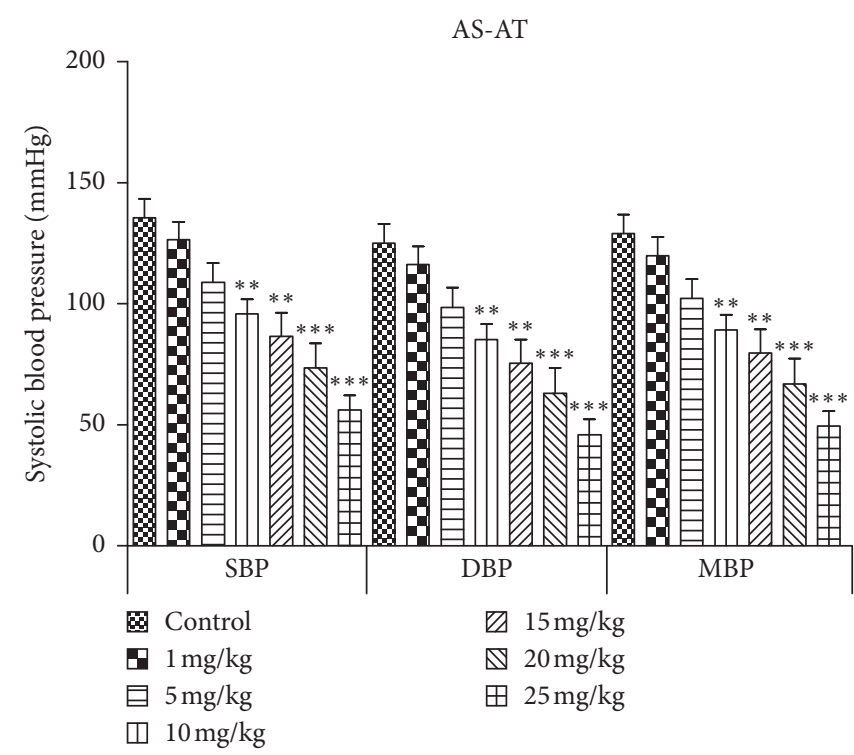

(b)

FIGURE 3: Effect of various doses of (a) Asphodelus tenuifolius crude extract (AT-Cr) and (b) aqueous soluble fraction of A. tenuifolius (AS$\mathrm{AT}$ ) in anesthetized normotensive rats on systolic blood pressure (SBP), diastolic blood pressure (DBP), and mean arterial pressure (MAP). Results are stated as mean \pm SEM, whereas ${ }^{*}=P<0.05$ and ${ }^{* * *}=P<0.001$ when compared to the normal saline-treated group.

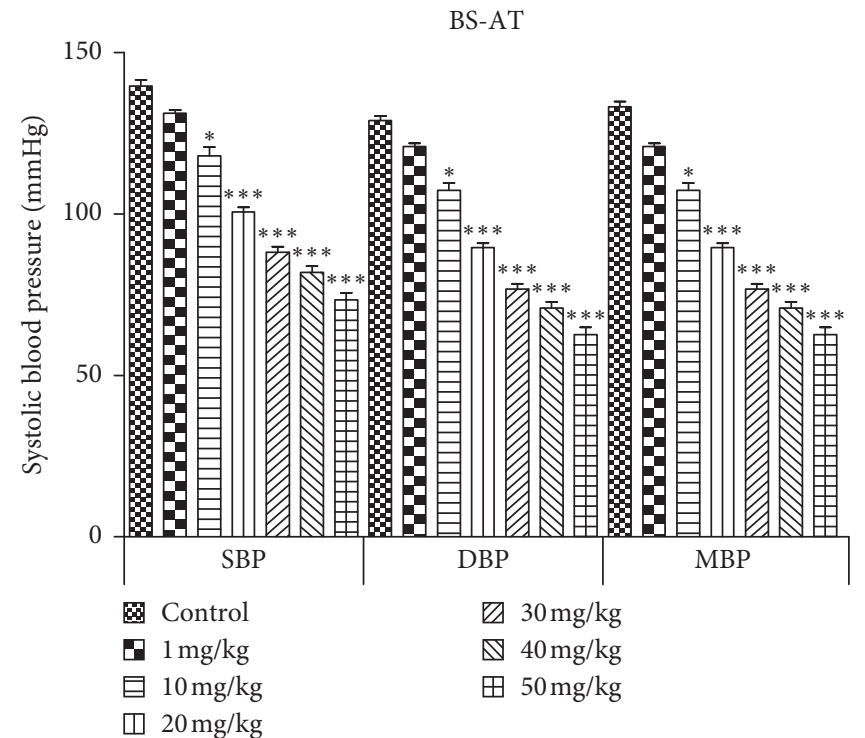

(a)

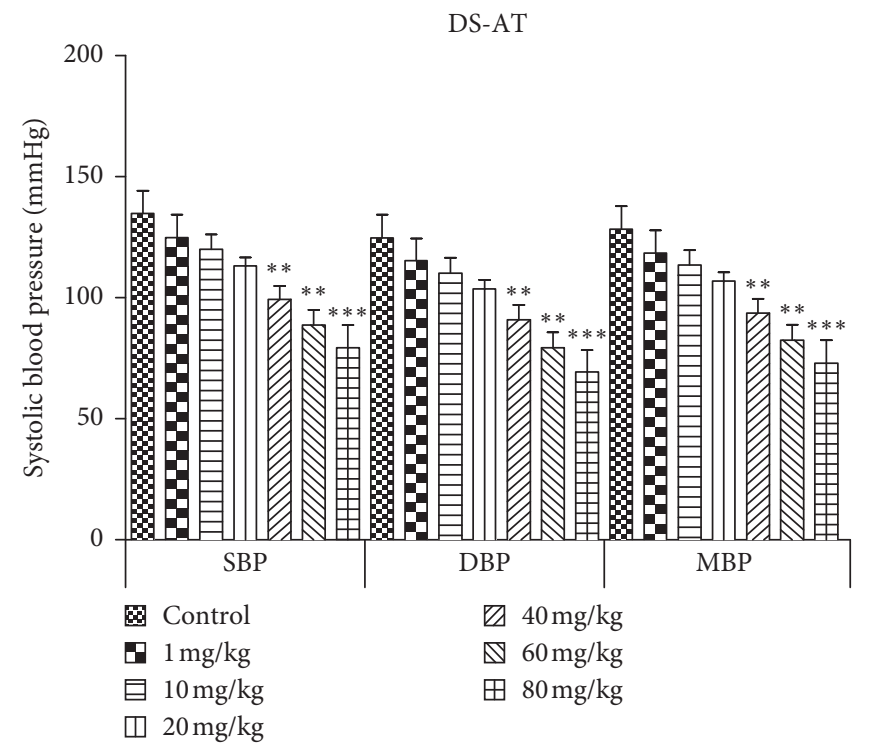

(b)

Figure 4: Effect of various doses of (a) butanol soluble fraction of A. tenuifolius (BS-AT) and (b) dichloromethane soluble fraction of A. tenuifolius (DS-AT) in anesthetized normotensive rats on systolic blood pressure (SBP), diastolic blood pressure (DBP), and mean blood pressure (MBP). Results are stated as mean \pm SEM, whereas ${ }^{*}=P<0.05$ and ${ }^{* * *}=P<0.001$ as compared to the normal saline-treated group.

\subsection{Results of Diuretic Studies of A. tenuifolius Extract/ Fractions}

3.4.1. Acute Diuretic Effect. (1) Effect of A. tenuifolius Extract/Fractions on Urine Volume. Acute diuretic effect with AT-Cr $(100,200$, and $300 \mathrm{mg} / \mathrm{kg})$, AS-AT $(100,200$, and $300 \mathrm{mg} / \mathrm{kg})$, BS-AT $(100,200$, and $300 \mathrm{mg} / \mathrm{kg})$, DS-AT (100, 200 , and $300 \mathrm{mg} / \mathrm{kg})$, and hydrochlorothiazide $(10 \mathrm{mg} / \mathrm{kg})$ is presented in Tables 3 and 4. AT-Cr $(300 \mathrm{mg} / \mathrm{kg})$, BS-AT $(300 \mathrm{mg} / \mathrm{kg})$, and DS-AT $(300 \mathrm{mg} / \mathrm{kg})$ increased the urine output at 6 th $\mathrm{h}$ after the treatment whereas AS-AT (200 and $300 \mathrm{mg} / \mathrm{kg}$ ) produced a highly significant increase in urinary output after 4 and $6 \mathrm{~h}$ of treatment. Also, the total urine volume calculated at 4 and $6 \mathrm{~h}$ in $300 \mathrm{mg} / \mathrm{kg}$ AS-AT treated rats was $4.96 \pm 0.75$ and $7.19 \pm 0.7 \mathrm{~mL} / 100 \mathrm{~g}$, respectively, whereas the urinary output of rats in the control group after 


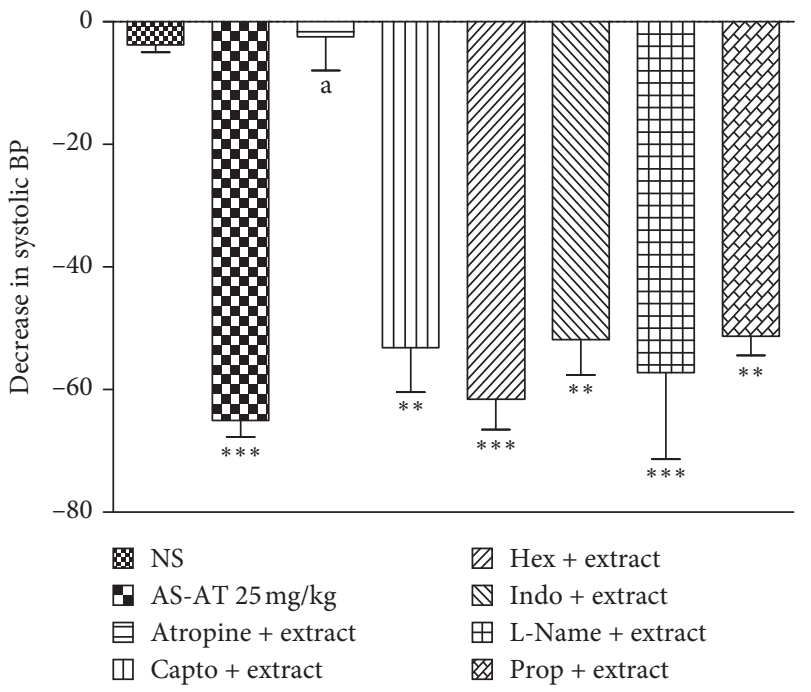

FIGURE 5: Effect of the aqueous soluble fraction of A. tenuifolius (AS-AT, $25 \mathrm{mg} / \mathrm{kg}$ ) on systolic BP in rats pretreated with various antagonists. Results are stated as mean \pm SEM, whereas ${ }^{* *}=P<0.01$ and ${ }^{* * *}=P<0.001$ as compared to normal saline- (NS-) treated group, while $a=P<0.001$ when compared to the extract-treated control. The figure shows a decrease in systolic BP with AS-AT (25 mg/kg) in anesthetized rats pretreated with normal saline (NS $1 \mathrm{ml} / \mathrm{kg})$, hexamethonium $(30 \mathrm{mg} / \mathrm{kg})$, atropine $(2 \mathrm{mg} / \mathrm{kg})$, captopril $(2.5 \mathrm{mg} / \mathrm{kg})$, indomethacin $(5 \mathrm{mg} / \mathrm{kg})$, L-Name $(20 \mathrm{mg} / \mathrm{kg})$, and propranolol (Prop $1 \mathrm{mg} / \mathrm{kg}$ ).

Table 3: Effect of $A$. tenuifolius extract/fractions on urine and electrolyte excretion.

\begin{tabular}{|c|c|c|c|c|c|c|}
\hline \multirow{2}{*}{ Treatment $(\mathrm{mg} / \mathrm{kg})$} & \multicolumn{3}{|c|}{ Urine volume $(\mathrm{ml} / 100 \mathrm{gm})$} & \multirow{2}{*}{$\mathrm{Na}^{+}(\mathrm{mEq} / \mathrm{L})$} & \multirow{2}{*}{$\mathrm{K}^{+}(\mathrm{mEq} / \mathrm{L})$} & \multirow{2}{*}{$\mathrm{pH}$} \\
\hline & $2 \mathrm{~h}$ & $4 \mathrm{~h}$ & $6 \mathrm{~h}$ & & & \\
\hline NS & $1.42 \pm 0.30$ & $2.39 \pm 0.05$ & $3.5 \pm 0.12$ & $113.6 \pm 13$ & $40 \pm 1.2$ & $6.89 \pm 0.12$ \\
\hline HCTZ 10 mg/kg & $2.8 \pm 0.43$ & $4.04 \pm 0.34^{*}$ & $7.14 \pm 0.6^{* * *}$ & $173 \pm 11^{* * *}$ & $56 \pm 5.1^{*}$ & $6.92 \pm 0.72$ \\
\hline AT-Cr 100 mg/kg & $1.3 \pm 0.25$ & $2.54 \pm 0.39$ & $3.35 \pm 0.5$ & $128.3 \pm 3$ & $45.3 \pm 4.8$ & $6.65 \pm 0.27$ \\
\hline AT-Cr 200 mg/kg & $2.44 \pm 0.20$ & $3.25 \pm 0.42$ & $5.5 \pm 0.59^{* * *}$ & $135 \pm 3^{*}$ & $52.3 \pm 3.9$ & $6.71 \pm 0.18$ \\
\hline AT-Cr 300 mg/kg & $2.55 \pm 0.38$ & $3.44 \pm 0.7$ & $6.39 \pm 0.8^{* * *}$ & $160 \pm 2^{* * *}$ & $59.3 \pm 8.6^{*}$ & $6.69 \pm 0.45$ \\
\hline AS-AT $100 \mathrm{mg} / \mathrm{kg}$ & $2.60 \pm 0.44$ & $4.03 \pm 0.31^{*}$ & $5.28 \pm 0.4^{*}$ & $121 \pm 4$ & $45 \pm 2.3$ & $6.71 \pm 0.98$ \\
\hline AS-AT $200 \mathrm{mg} / \mathrm{kg}$ & $2.73 \pm 0.46$ & $4.57 \pm 0.34^{* *}$ & $5.68 \pm 0.52^{* *}$ & $132 \pm 3^{*}$ & $52.3 \pm 6.1$ & $6.78 \pm 0.29$ \\
\hline AS-AT $300 \mathrm{mg} / \mathrm{kg}$ & $2.86 \pm 0.10$ & $4.96 \pm 0.75^{* *}$ & $7.19 \pm 0.7^{* * *}$ & $221 \pm 18^{* * *}$ & $66 \pm 11^{*}$ & $6.91 \pm 0.23$ \\
\hline BS-AT 100 mg/kg & $1.74 \pm 0.06$ & $2.31 \pm 0.60$ & $3.77 \pm 0.26$ & $117.6 \pm 2.2$ & $39.6 \pm 7.09$ & $6.70 \pm 0.23$ \\
\hline BS-AT $200 \mathrm{mg} / \mathrm{kg}$ & $1.90 \pm 0.10$ & $3.05 \pm 0.20$ & $4.89 \pm 0.22^{*}$ & $125 \pm 1.5$ & $43 \pm 2.5$ & $6.69 \pm 0.18$ \\
\hline BS-AT $300 \mathrm{mg} / \mathrm{kg}$ & $2.28 \pm 0.17$ & $3.21 \pm 0.23$ & $5.67 \pm 0.22^{*}$ & $131 \pm 5^{*}$ & $47.6 \pm 2.9$ & $6.74 \pm 0.89$ \\
\hline DS-AT $100 \mathrm{mg} / \mathrm{kg}$ & $1.33 \pm 0.17$ & $2.81 \pm 0.30$ & $4.02 \pm 0.47$ & $121 \pm 8$ & $40.3 \pm 7.5$ & $6.56 \pm 0.45$ \\
\hline DS-AT $200 \mathrm{mg} / \mathrm{kg}$ & $2.04 \pm 0.69$ & $3.12 \pm 0.36$ & $5.1 \pm 0.49^{*}$ & $130 \pm 15^{*}$ & $43.3 \pm 4.9$ & $6.61 \pm 0.78$ \\
\hline DS-AT $300 \mathrm{mg} / \mathrm{kg}$ & $2.39 \pm 0.88$ & $3.44 \pm 0.45$ & $5.69 \pm 0.69^{*}$ & $135 \pm 3^{*}$ & $42.3 \pm 3.9$ & $6.68 \pm 0.40$ \\
\hline
\end{tabular}

Results are stated as mean \pm SEM where ${ }^{*}=P<0.05,{ }^{* *}=P<0.01$, and ${ }^{* * *}=P<0.001$, as compared to normal saline- (NS-) treated group. HCTZ $=$ hydrochlorothiazide, AT-Cr $=$ crude extract of A. tenuifolius, AS-AT $=$ aqueous soluble fraction of $A$. tenuifolius, BS-AT $=$ butanol soluble fraction of A. tenuifolius, and DS-AT $=$ dichloromethane soluble fraction of A. tenuifolius.

4 and 6 hours was $2.39 \pm 0.05$ and $3.51 \pm 0.12 \mathrm{~mL} / 100 \mathrm{~g}$, respectively. Moreover, urinary output at 4 and 6 hours in rats treated with AS-AT $(300 \mathrm{mg} / \mathrm{kg})$ was very similar to the output in rats treated with HCTZ, a standard diuretic drug. Urinary output data of various fractions also showed that urine excretion was increased as the polarity of the solvent increased suggesting that aqueous soluble fractions contain various polar compounds responsible for this activity.

(2) Effect of A. tenuifolius Extract/Fractions on Electrolyte Excretion. Effects of treatment with HCTZ $(10 \mathrm{mg} / \mathrm{kg})$, AT-Cr $(100-300 \mathrm{mg} / \mathrm{kg}), \quad$ AS-AT $\quad(100-300 \mathrm{mg} / \mathrm{kg}), \quad$ BS-AT $(100-300 \mathrm{mg} / \mathrm{kg})$, and DS-AT $(100-300 \mathrm{mg} / \mathrm{kg})$ on the excretion of sodium and potassium are presented in Tables 3 and 4 . AT-Cr, at 200 and $300 \mathrm{mg} / \mathrm{kg}$, caused a significant increase in the urinary sodium and potassium excretion whereas BS-AT and DS-AT only enhance the urinary sodium excretion at its maximum dose $(300 \mathrm{mg} / \mathrm{kg})$, with a very slight effect on potassium excretion. In contrast, AS-AT at $200 \mathrm{mg}$ / $\mathrm{kg}$ caused a significant increase in sodium excretion with a very low effect on potassium excretion, while, at $300 \mathrm{mg} / \mathrm{kg}$, it caused a highly significant $(P<0.001)$ increase in both sodium and potassium urinary excretion. In fact, sodium and potassium excretion induced by AS-AT was $221 \pm 18$ and $66 \pm 11$, while in the control group, it was $113.6 \pm 13$ and $40 \pm 1.2 \mathrm{~mL} / 100 \mathrm{~g} / 6 \mathrm{~h}$. Moreover, AS-AT-induced electrolyte excretion was not different than HCTZ-induced electrolyte excretion. These findings present notable parallelism in sodium and urine excretion. Finally, the $\mathrm{pH}$ values in all the 
Table 4: Effect of A. tenuifolius extract/fractions on the diuretic index, Saluretic index, Lipschitz value, and excretion load.

\begin{tabular}{|c|c|c|c|c|c|c|c|c|}
\hline Treatment $(\mathrm{mg} / \mathrm{kg})$ & $\mathrm{Na} / \mathrm{k}$ & $\begin{array}{l}\text { Diuretic index } \\
\text { (DI) }\end{array}$ & $\begin{array}{c}\text { Saluretic index } \mathrm{Na}^{+} \\
\left(\mathrm{SI}_{\mathrm{Na}}\right)\end{array}$ & $\begin{array}{c}\text { Saluretic index } \mathrm{K}^{+} \\
\left(\mathrm{SI}_{\mathrm{K}}\right)\end{array}$ & $\begin{array}{l}\text { Saluretic index } \\
\text { (SI) }\end{array}$ & $\begin{array}{c}\text { Lipschitz value } \\
\text { (LV) }\end{array}$ & $\begin{array}{c}\mathrm{EL} \\
\mathrm{Na}^{+} \\
\end{array}$ & $\begin{array}{l}\mathrm{EL} \\
\mathrm{K}^{+} \\
\end{array}$ \\
\hline NS & 2.84 & 1.00 & 1.00 & 1.00 & 1 & 0.49 & 1.003 & 0.310 \\
\hline HCTZ 10 mg/kg & 4.80 & 2.03 & 1.53 & 1.4 & 1.465 & 1.00 & 3.287 & 1.11 \\
\hline AT-Cr 100 mg/kg & 2.83 & 0.954 & 1.129 & 1.132 & 1.130 & 0.46 & 1.19 & 0.42 \\
\hline AT-Cr $200 \mathrm{mg} / \mathrm{kg}$ & 2.58 & 1.581 & 1.188 & 1.307 & 1.247 & 0.77 & 2.02 & 0.78 \\
\hline AT-Cr 300 mg/kg & 2.69 & 1.820 & 1.411 & 1.482 & 1.445 & 0.86 & 2.72 & 1.008 \\
\hline AS-AT $100 \mathrm{mg} / \mathrm{kg}$ & 2.68 & 1.503 & 1.065 & 1.125 & 1.095 & 0.78 & 1.69 & 0.63 \\
\hline AS-AT $200 \mathrm{mg} / \mathrm{kg}$ & 2.93 & 1.617 & 1.161 & 1.307 & 1.484 & 0.70 & 1.98 & 0.784 \\
\hline AS-AT $300 \mathrm{mg} / \mathrm{kg}$ & 3.348 & 2.04 & 1.948 & 1.65 & 1.75 & 0.78 & 4.20 & 1.254 \\
\hline BS-AT $100 \mathrm{mg} / \mathrm{kg}$ & 2.95 & 1.077 & 1.035 & 0.99 & 1.012 & 0.528 & 1.23 & 0.414 \\
\hline BS-AT $200 \mathrm{mg} / \mathrm{kg}$ & 2.90 & 1.39 & 1.10 & 1.075 & 1.087 & 0.68 & 1.69 & 0.58 \\
\hline BS-AT $300 \mathrm{mg} / \mathrm{kg}$ & 2.75 & 1.62 & 1.15 & 1.19 & 1.17 & 0.79 & 2.06 & 0.749 \\
\hline DS-AT $100 \mathrm{mg} / \mathrm{kg}$ & 2.57 & 1.144 & 1.070 & 1.182 & 1.125 & 0.56 & 1.33 & 0.52 \\
\hline DS-AT $200 \mathrm{mg} / \mathrm{kg}$ & 2.74 & 1.566 & 1.237 & 1 & 1.118 & 0.77 & 2.10 & 0.60 \\
\hline DS-AT $300 \mathrm{mg} / \mathrm{kg}$ & 2.59 & 1.621 & 1.188 & 1.307 & 1.247 & 0.79 & 2.02 & 0.784 \\
\hline
\end{tabular}

$\mathrm{NS}=$ normal saline, $\mathrm{HCTZ}=$ hydrochlorothiazide, AT-Cr=crude extract of A. tenuifolius, AS-AT=aqueous soluble fraction of A. tenuifolius, BS$\mathrm{AT}=$ butanol soluble fraction of A. tenuifolius, DS-AT = dichloromethane soluble fraction of A. tenuifolius. $\mathrm{DI}=$ urine volume of extract-treated group/urine volume of NS-treated group. $\mathrm{SI}_{\mathrm{Na}}=$ urine $\mathrm{Na}^{+}$excretion of extract-treated group/urine $\mathrm{Na}^{+}$excretion of NS-treated group, $\mathrm{SI}_{\mathrm{K}}=\mathrm{Urine}^{+}$excretion of extract-treated group/urine $\mathrm{K}^{+}$excretion of NS-treated group, $\mathrm{SI}=\mathrm{SI}_{\mathrm{Na}}+\mathrm{SI}_{\mathrm{K}}$ of treated group $/ \mathrm{SI}_{\mathrm{Na}}+\mathrm{SI}_{\mathrm{K}}$ of the control group, $\mathrm{LV}=$ urine volume of extracttreated group/urine volume of HCTZ-treated group, Excretion load $(\mathrm{EL})=$ electrolytes concentration $(\mathrm{mEq} / \mathrm{l}) \times$ urinary flow $(\mathrm{ml} / \mathrm{min})$.

groups were not different than the control group. Based upon the highly significant increase in urine output and electrolyte excretion, AS-AT $(300 \mathrm{mg} / \mathrm{kg})$ was selected for prolonged treatment and for evaluating the mechanism underlying its diuretic activity.

3.5. Prolong Diuretic Activity of AS-AT. Treatment with ASAT $(300 \mathrm{mg} / \mathrm{kg})$ for continuous 7 days significantly increased the urine output (Figure 6). There was also a significant increase in sodium and potassium excretion on the 7th day after treatment with $300 \mathrm{mg} / \mathrm{kg}$ AS-AT. These results were very similar to classical diuretic HCTZ.

\subsection{Mechanism Underlying the Diuretic Potential of AS-AT}

3.6.1. AS-AT-Induced Diuresis through Muscarinic Receptors. Pretreatment with atropine significantly prevented the ASAT-induced diuresis and electrolyte excretion (Figure 7) whereas L-NAME and indomethacin did not alter the ability of AS-AT to induce diuresis.

3.6.2. AS-AT Did Not Inhibit Angiotensin-Converting Enzyme (ACE), Erythrocyte Carbonic Anhydrase, and Renal $\mathrm{Na}+/ \mathrm{K}+/$ ATPase Activity. Treatment with AS-AT did not inhibit ACE activity whereas standard ACE inhibitor, captopril, inhibited the ACE activity around 53\% (Figure 8(a)). Treatment with AS-AT did not alter the erythrocyte carbonic anhydrase activity whereas typical carbonic anhydrase inhibitor, acetazolamide, inhibited it by $55 \pm 5 \%$ (Figure 8(b)). Moreover, AS-AT $(3-30 \mu \mathrm{M})$ did not change in vitro renal $\mathrm{Na}+/ \mathrm{K}+/ \mathrm{ATPase}$ activity (Figure $8(\mathrm{c})$ ).

\section{Discussion}

Hypertension has been a global health problem owing to its recurrent incidence, incessant, and uncontrolled threat for associated cardiovascular and kidney diseases [32]. According to an estimation by the world health organization (WHO), presently, 17.1 million deaths are happening each year worldwide due to different CVDs [33]. Owing to lifelong use and undesired effects of current allopathic drugs, research has been inclined towards the discovery of novel, curative, and safe therapeutic agents of natural origin for the management of CVDs [34]. Ethnopharmacology has been used as a successful tool to find new strategies and candidates for novel drugs and herbal medicines [35]. Since ancient times, medicinal plants have led to the development of highly effective tools for therapeutic purposes. Numerous studies have revealed that several plants have been pharmacologically evaluated based upon their empirical usage for the therapy of hypertension, and many of the currently marketed pharmaceutical drugs are synthesized based upon phytoconstituents isolated from these plants [1,36]. Due to these reasons, in the current study, Asphodelus tenuifolius have been selected based upon the popular usage in diuresis and hypertension, for thorough pharmacological appraisal.

Data obtained in this study indicates a possible role of A. tenuifolius as an antihypertensive drug for the treatment of several CVDs. Our data showed the hypotensive and diuretic potential of $A$. tenuifolius, and according to our results, these effects appear to be attributed to the activation of muscarinic receptors. In fact, the hypotensive effect of aqueous fraction of $A$. tenuifolius (AS-AT) was not altered in the presence of L-NAME, indomethacin, or hexamethonium whereas atropine, a nonselective muscarinic acetylcholine receptor antagonist, significantly reduced the hypotensive response of AS-AT. In the vascular system, nitric oxide (NO) and prostacyclin (PGI2) regulate directly the arteriolar tone and consequently blood pressure levels. The main activator of NO and PGI2 synthesis in the vascular system is $\mathrm{Ca} 2+$. If $\mathrm{Ca} 2+$ levels rise, nitric oxide synthase (NOS) detaches from a protein called caveolin and is activated [37]. In addition, calcium catalyzes the activation of phospholipase A2, an 


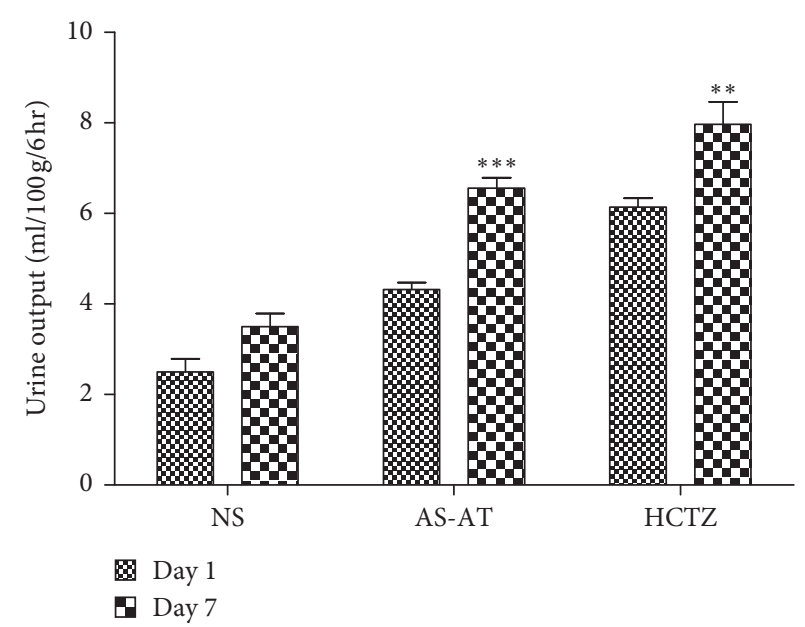

(a)

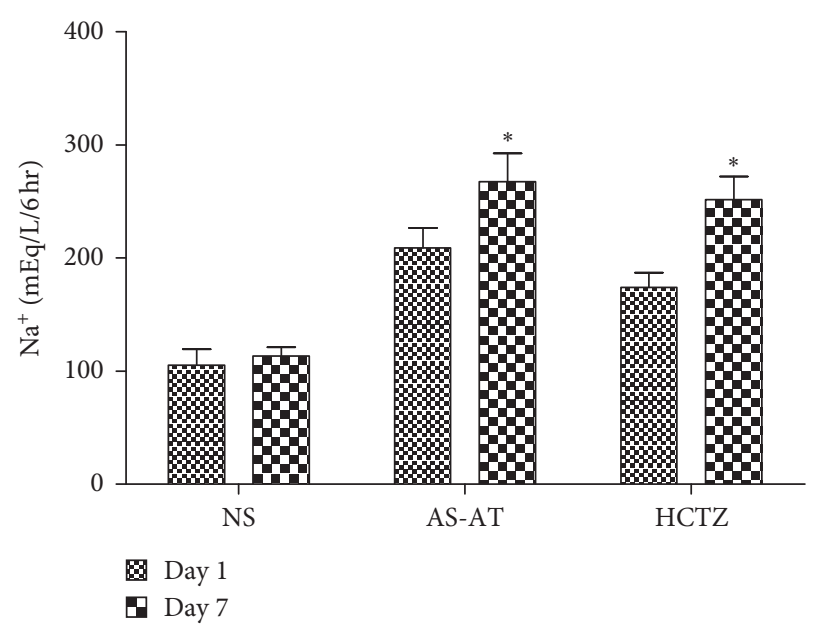

(b)

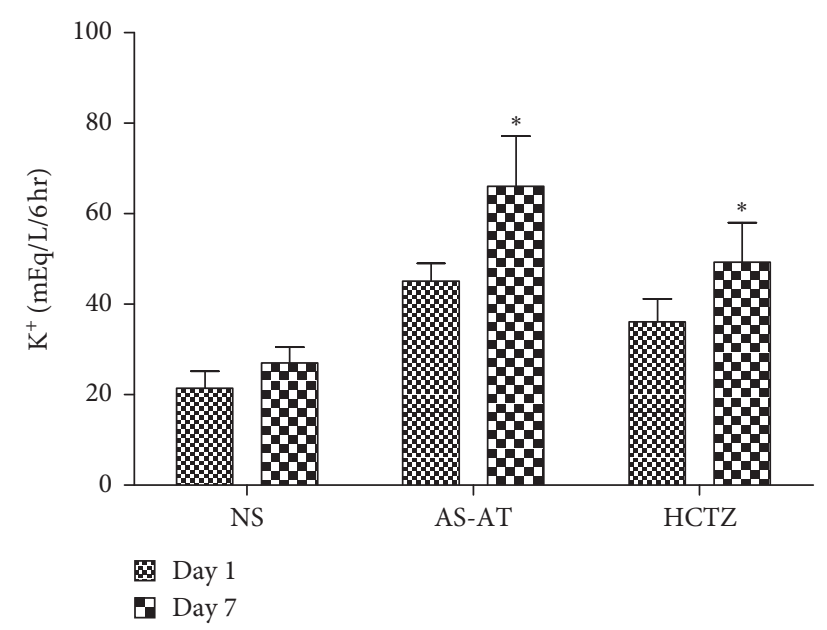

(c)

Figure 6: Effect of daily administration of aqueous soluble fraction of $A$. tenuifolius (AS-AT $300 \mathrm{mg} / \mathrm{kg}$ ) for 7 days on (a) urine output, (b) $\mathrm{Na}^{+}$excretion, and (c) $\mathrm{K}^{+}$excretion. Results are stated as mean $\pm \mathrm{SEM}$, whereas ${ }^{* *}=P<0.01$ and ${ }^{* * *}=P<0.001$ when compared to the normal saline- (NS-) treated group. All data are subjected to two-way ANOVA followed by Bonferroni posttest. HCTZ= hydrochlorothiazide.

important enzyme involved in the synthesis of PGI2. Currently, the role of acetylcholine on intracellular calcium levels is well established [38]. In vascular endothelium, M3 receptors may activate phospholipase $\mathrm{C}$ by increasing the inositol triphosphate (IP3) levels, which mobilizes Ca2+ from the cellular sarcoplasmic reticulum. Thus, substances capable of stimulating the M3 receptors may increase the release of NO and PGI2 and therefore reduce peripheral resistance and blood pressure. On the other hand, a recent study conducted by Tangsucharit et al. [39] has shown that the acetylcholine M1 and M3 receptors can also induce endothelium-independent vasodilation. In fact, removal of the endothelium in rat mesenteric arteries significantly decreased the levels of expression of M2 and M3, but not of M1. In mesenteric vascular beds denuded of the endothelium, ACh administration (10 and $100 \mathrm{nmol}$ ) caused longlasting vasodilation, which was markedly blocked by treatment with highly selective antagonists, including pirenzepine (M1 antagonist) and 4-DAMP (M1 and M3 antagonists). These results suggest that the AChR muscarinic subtypes, mainly M1, are distributed by the rat mesenteric arteries and that the activation of M1 and/or M3, which may be located in the peptidergic nerves, releases calcitonin generelated peptide (CGRP), causing vasodilation independent of the endothelium. Thus, as atropine is a nonselective muscarinic antagonist, it was able to block the effects of ASAT, while L-NAME and indomethacin, which inhibit endothelial mediators (i.e., NO and PGI2), did not show this ability.

It has also been recognized that diuretics are the backbone of treatment for hypertension and edematous states characterized by surplus extracellular fluid [40]. Usually, diuretics enhance the excretion of large amounts of water and salts from the body in order to decrease blood volume and blood pressure and therefore reduce blood flow resistance. Despite the abundant availability of diuretics for use in humans, such medicines are related to different side effects majorly including various metabolic complaints, 


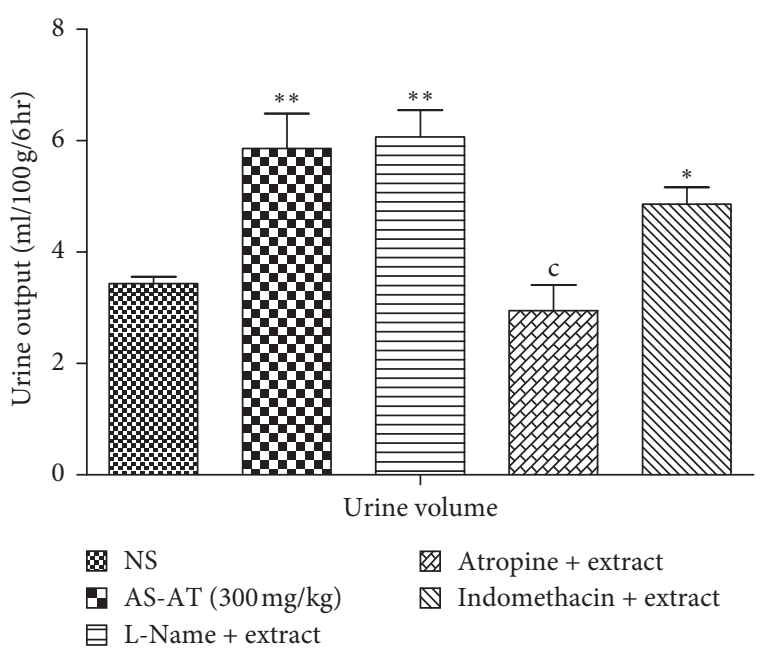

(a)

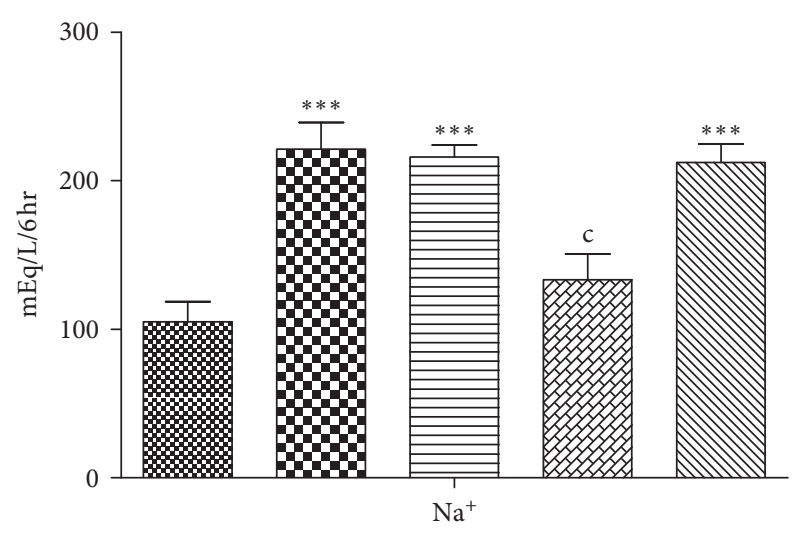

$\begin{array}{ll}\text { ⿴囗十 } \mathrm{NS} & \text { Atropine + extract } \\ \text { D AS-AT }(300 \mathrm{mg} / \mathrm{kg}) & \mathbb{Q} \text { Indomethacin + extract }\end{array}$

(b)

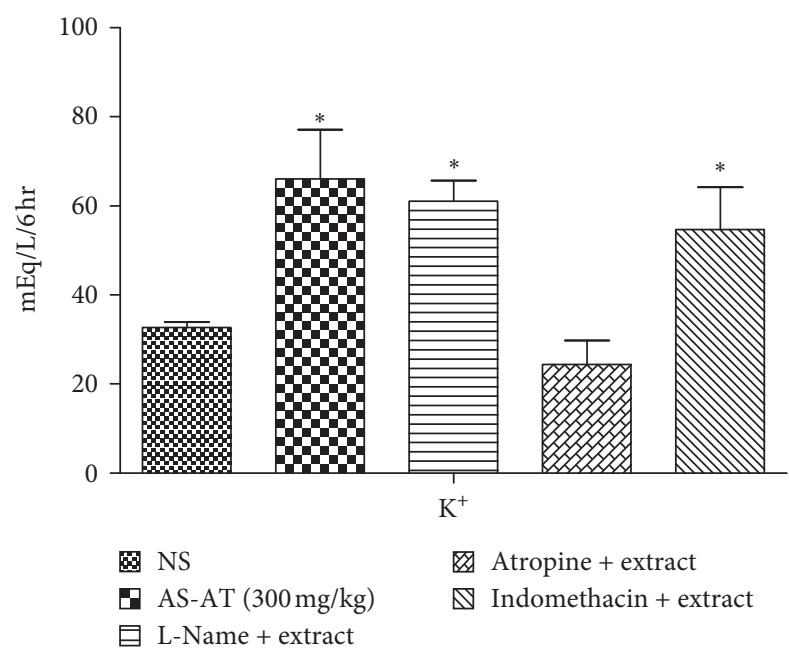

(c)

Figure 7: Effect of the aqueous soluble fraction of $A$. tenuifolius (AS-AT $300 \mathrm{mg} / \mathrm{kg}$ ) on (a) urine output (b) $\mathrm{Na}^{+}$excretion, and (c) $\mathrm{K}^{+}$ excretion in the presence of various antagonists. Results are stated as mean $\pm \mathrm{SEM}$, whereas ${ }^{*}=P<0.05$ and ${ }^{* * *}=P<0.001$ when compared to the normal saline-treated group, and $c=P<0.05$ when compared to the treated group (AS-AT). Rats in the control group received normal saline $(5 \mathrm{~mL} / 100 \mathrm{~g})$, while in all other groups, the animals received normal saline (NS $5 \mathrm{~mL} / 100 \mathrm{~g}), \mathrm{L}-\mathrm{Name}(60 \mathrm{mg} / \mathrm{kg})$, atropine $(1 \mathrm{mg} / \mathrm{kg})$, and indomethacin $(10 \mathrm{mg} / \mathrm{kg}) 1$ hour prior to administration of AS-AT $(300 \mathrm{mg} / \mathrm{kg})$.

strengthening the significance of rummage around for new diuretic agents with more efficacy and fewer side effects. Therefore, in the current situation, new diuretic medicines are planned primarily from natural sources [7]. In fact, several medicinal plants display a number of pharmacological properties on the renal system, acting on different well-established targets such as nitric oxide-cGMP, renal carriers, carbonic anhydrase, prostaglandin-cAMP, and renin-angiotensin systems [41]. In the current study, crude extracts and fractions from $A$. tenuifolius induced significant diuretic and natriuretic effects in normotensive rats, with maximum diuretic response produced by AS-AT. Similar to hypotensive effects, AS-AT was subjected to further studies to evaluate the possible involvement of nitric oxide, acetylcholine, and prostaglandins in the renal action. In our study, we found that diuretic activity of AS-
AT was reduced in the presence of muscarinic receptor blocker (atropine) whereas prostaglandin inhibitor (indomethacin) and NO synthesis inhibitor (L-NAME) did not alter the diuretic action. Thus, our findings suggest a muscarinic AChR-induced endothelium-independent vasodilation, which increases capillary blood flow leading to diuresis [42].

Oxidative stress has been the major underlying factor in the pathogenesis of various cardiovascular disorders like metabolic syndrome, diabetes, hypertension, kidney diseases, and heart failure owing to the rich supply of NADPH oxidase-induced ROS in vasculature and kidney. A high burden of ROS in the renal medulla will reduce the medullary blood flow and sodium excretion, resulting in high blood pressure and renal injury [43]. In the current study, various extract/fractions of A. tenuifolius seeds 


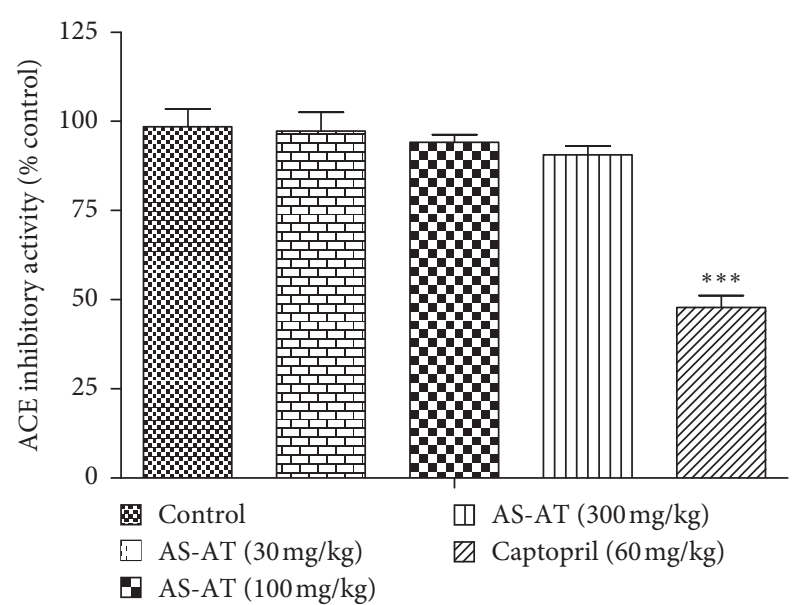

(a)

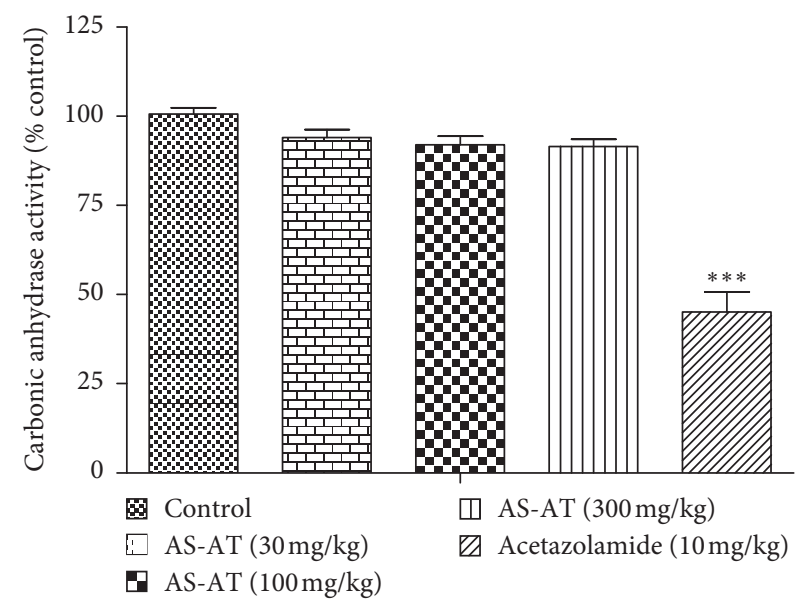

(b)

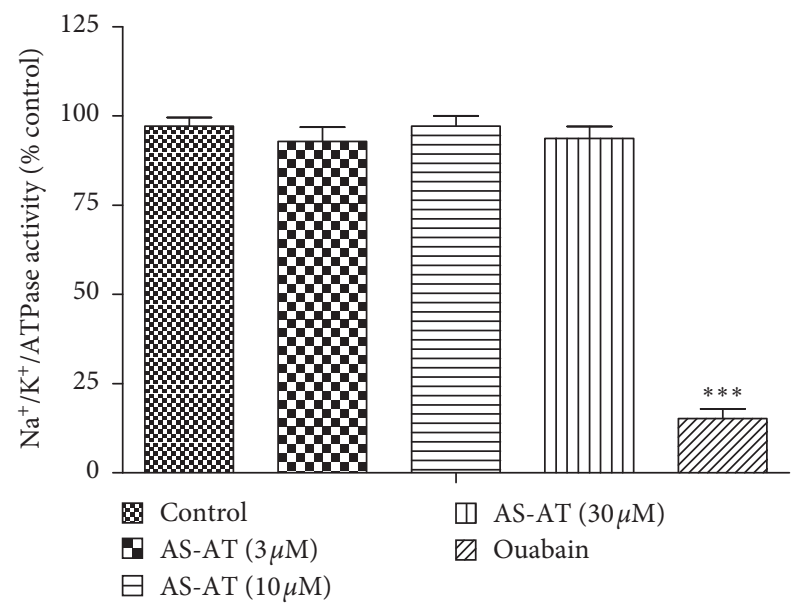

(c)

Figure 8: Effect of the aqueous soluble fraction of A. tenuifolius (AS-AT) on (a) ACE inhibitory activity, (b) erythrocyte carbonic anhydrase activity, and (c) renal $\mathrm{Na}^{+} / \mathrm{K}^{+} / \mathrm{ATPase}$ activity. Results are stated as mean $\pm \mathrm{SEM}$, whereas ${ }^{* * *}=P<0.001$ when compared to normal salinetreated group (control).

showed significant DPPH and nitric oxide (NO-) free radical scavenging ability, which is in line with the previously reported antioxidant potential of whole plant extract [9]. Therefore, we believe that the antioxidant effects presented by $A$. tenuifolius extract and their fractions may, directly or indirectly, contribute to the diuretic and hypotensive activities.

Preceding phytochemical studies of A. tenuifolius with GCMS analysis have reported 20 different chemical constituents including some famous antioxidant compounds such as 5hydroxymethylfurfural, 2, 3-dihydro-3, 5-dihydroxy-6-methyl4H-pyran-4-one, cis-stilbene, and 2, 5-dimethyl-4-hydroxy$3(2 \mathrm{H})$-furanone (DMHF) [44, 45]. Moreover, many polyphenols, such as quercetin, rutin, apigenin, caffeic acid, and myricetin, were also identified in A. tenuifolius extract by HPLC-DAD. These polyphenols have been reported for their antihypertensive effects in various studies [46-50]. In this work, we analyzed the extract and fractions from A. tenuifolius by LC-DAD-MS, and seventeen compounds were described from AS-AT. The annotated compounds include organic acids, sugars, alkaloids, nucleoside, and glycosylated flavonoids. The molecular network revealed the components in the most active sample AS-AT compared to the other samples, and four major node cluster families were observed, which include glycosylated flavonoids and alkaloids. Thus, we believe that the presence of such constituents in A. tenuifolius extracts could be responsible for their hypotensive and diuretic potential. One of the limitations of our study was not being able to identify which compound found in AS-AT may be responsible for its cardiorenal activities. Despite this, we conjectured that this effect should not be attributed to only one representative but rather to coordinated and synergistic action of the various metabolites present in AS-AT.

\section{Conclusion}

This research supports and extends the traditional use of A. tenuifolius as a hypotensive and diuretic agent. The results showed that AS-AT from A. tenuifolius could present compounds responsible for hypotensive and diuretic activities with no signs of toxicity, and these effects could involve activation of muscarinic receptors. 


\section{Abbreviations}

ACE: Angiotensin-converting enzyme

AS-AT: Aqueous soluble fraction of A. tenuifolius

BS-AT: Butanol soluble fraction of A. tenuifolius

DS-AT: Dichloromethane soluble fraction of $A$. tenuifolius

AT-Cr: Crude extract of $A$. tenuifolius

CVD: Cardiovascular diseases

HCTZ: Hydrochlorothiazide

NO: Nitric oxide

ROS: Reactive oxygen species

TAC: Total antioxidant capacity

TFC: $\quad$ Total flavonoid contents

TPC: Total phenolic contents

TRP: Total reducing power

WHO: World Health Organization.

\section{Data Availability}

All original data supporting the current study has been provided in this article.

\section{Ethical Approval}

Animal care and experimental procedures used in the current study were approved by the Institutional Animal Ethical Committee of College of Pharmacy, University of Sargodha (Approval No. IAEC/UOS/2016/46).

\section{Conflicts of Interest}

The authors declare that they have no conflicts of interest.

\section{Authors' Contributions}

Waqas Younis performed experiments and collected data from various activities. Alamgeer and V. B. Schini-Kerth designed this study and provided the necessary facilities for experiments. Priscila de Souza and Arquimedes Gasparotto Junior provided help in diuretic assays and the correction of the manuscript. Denise Brentan Silva and Samara Requena Nocchi performed the chemical analyses and described the information about the chemical constituents. Ishfaq Ali Bukhari, Fahim Vohra, and Sibtain Afzal also helped in conducting the study and writing of the research paper. All authors read and approved the final manuscript.

\section{Acknowledgments}

The authors extend their appreciation to the Deanship of Scientific Research at King Saud University for funding this work through research group NO- (RG-1439-002). The authors are thankful to the Higher Education Commission of Pakistan, Ministry of Foreign Affairs and International Development (MAEDI) of France, and the Ministry of Higher Education and Research (MESR) of France for funding this project through the PERIDOT Research Program. The authors are also thankful to the ORIC department of the University of Sargodha for funding this research project.

\section{References}

[1] S. S. Al Disi, M. A. Anwar, and A. H. Eid, "Anti-hypertensive herbs and their mechanisms of action: Part I," Frontiers in Pharmacology, vol. 6, p. 323, 2016.

[2] Ü. Karaca, M. T. Schram, A. J. H. M. Houben, D. M. J. Muris, and C. D. A. Stehouwer, "Microvascular dysfunction as a link between obesity, insulin resistance and hypertension," Diabetes Research and Clinical Practice, vol. 103, no. 3, pp. 382-387, 2014.

[3] Y. Huan, D. L. Cohen, and R. R. Townsend, "Pathophysiology of hypertension in chronic kidney disease," Chronic Renal Disease, vol. 2, pp. 163-169, 2015.

[4] Y. Opsha, "Diuretics," Side Effects of Drugs Annual, vol. 38, pp. 185-191, 2016.

[5] T. Morgan, A. I. Anderson, and R. J. MacInnis, "ACE inhibitors, beta-blockers, calcium blockers, and diuretics for the control of systolic hypertension," American Journal of $\mathrm{Hy}$ pertension, vol. 14, no. 3, pp. 241-247, 2001.

[6] H. Sternlicht and G. L. Bakris, "The kidney in hypertension," Medical Clinics of North America, vol. 101, no. 1, pp. 207-217, 2017.

[7] C. I. Wright, L. Van-Buren, C. I. Kroner, and M. M. G. Koning, "Herbal medicines as diuretics: a review of the scientific evidence," Journal of Ethnopharmacology, vol. 114, no. 1, pp. 1-31, 2007.

[8] A. Mahmood, A. Mahmood, H. Shaheen, R. A. Qureshi, Y. Sangi, and S. A. Gilani, "Ethno medicinal survey of plants from district Bhimber Azad Jammu and Kashmir," Journal of Medicinal Plant Research, vol. 5, no. 11, pp. 2348-2360, 2011.

[9] S. E. Laouini, A. Khelef, S. Ladjel, and M. R. Ouahrani, "A comparative study of the phytochemical, antioxidant and anti-inflammatory properties of ethyl acetate extract of Asphodelus tenuifolius Cav recovered by different extraction techniques," Annals of Science and Technology, vol. 7, no. 1, p. 10, 2015.

[10] N. Aslam, K. H. Janbaz, and Q. Jabeen, "Hypotensive and diuretic activities of aqueous-ethanol extract of Asphodelus tenuifolius," Bangladesh Journal of Pharmacology, vol. 11, no. 4, pp. 830-837, 2016.

[11] A. B. Rashid and S. K. Marwat, "Ethnobotanical study of important wild plants of bahadur khel tract (tehsil banda daud Shah) in karak district," Gomal University Journal of Research, vol. 2, no. 2, pp. 165-172, 2006.

[12] W. Murad, A. Azizullah, M. Adnan et al., "Ethnobotanical assessment of plant resources of banda daud Shah, district karak, Pakistan," Journal of Ethnobiology and Ethnomedicine, vol. 9, no. 1, p. 77, 2013.

[13] N. Ahmed, A. Mahmood, S. S. Tahir et al., "Ethnomedicinal knowledge and relative importance of indigenous medicinal plants of Cholistan desert, Punjab Province, Pakistan," Journal of Ethnopharmacology, vol. 155, no. 2, pp. 1263-1275, 2014.

[14] H. Ouhaddou, H. Boubaker, F. Msanda, and A. El Mousadik, "An ethnobotanical study of medicinal plants of the Agadir Ida Ou Tanane province (southwest Morocco)," Journal of Applied Biosciences, vol. 84, no. 1, pp. 7707-7722, 2014.

[15] W. Younis, V. B. Alamgeer, V. B. Schini-Kerth, A. G. Junior, and M. Majid, "Cardioprotective effect of Asphodelus tenuifolius Cav. on blood pressure and metabolic alterations in glucose-induced metabolic syndrome rats-An ethnopharmacological approach," Journal of Ethnopharmacology, vol. 214, p. 168, 2018. 
[16] C. Auger, P. Chabert, C. Lugnier, M. N. Mushtaq, and V. B. Schini-Kerth, "Mechanisms underlying vasorelaxation induced in the porcine coronary arteries by Thymus linearis Benth," Journal of Ethnopharmacology, vol. 225, pp. 211-219, 2018.

[17] S. E. L. Tolouei, C. A. S. Tirloni, R. A. C. Palozi et al., "Celosia argentea L. (Amaranthaceae) a vasodilator species from the Brazilian Cerrado-an ethnopharmacological report," Journal of Ethnopharmacology, vol. 229, pp. 115-126, 2019.

[18] M. Wang, J. J. Carver, V. V. Phelan et al., "Sharing and community curation of mass spectrometry data with global natural products social molecular networking," Nature Biotechnology, vol. 34, no. 8, pp. 828-837, 2016.

[19] E. N. L. Tom, C. Demougeot, O. B. Mtopi et al., "The aqueous extract of Terminalia superba (Combretaceae) prevents glucose-induced hypertension in rats," Journal of Ethnopharmacology, vol. 133, no. 2, pp. 828-833, 2011.

[20] S. T. Kau, J. R. Keddie, and D. Andrews, "A method for screening diuretic agents in the rat," Journal of Pharmacological Methods, vol. 11, no. 1, pp. 67-75, 1984.

[21] A. G. Junior, F. M. Gasparotto, E. L. Lourenço et al., “Antihypertensive effects of isoquercitrin and extracts from Tropaeolum majus L.: evidence for the inhibition of angiotensin converting enzyme," Journal of Ethnopharmacology, vol. 134 , no. 2, pp. 363-372, 2011.

[22] T. B. L. Prando, L. N. Barboza, V. d. O. Araújo et al., "Involvement of bradykinin B2 and muscarinic receptors in the prolonged diuretic and antihypertensive properties of Echinodorus grandiflorus (Cham. \& Schltdl.) Micheli." Phytomedicine, vol. 23, no. 11, pp. 1249-1258, 2016.

[23] R. E. Tashian, "The carbonic anhydrases: widening perspectives on their evolution, expression and function," BioEssays, vol. 10, no. 6, pp. 186-192, 1989.

[24] F. Noel and T. Godfraind, "Heterogeneity of ouabain specific binding sites and $(\mathrm{Na}++\mathrm{K}+)$-ATPase inhibition in microsomes from rat heart," Biochemical Pharmacology, vol. 33, no. 1, pp. 47-53, 1984.

[25] W. Younis, Alamgeer, V. B. Schini-Kerth et al., "Endothelium-independent vasorelaxant effect of Asphodelus tenuifolius Cav. via inhibition of myosin light chain kinase activity in the porcine coronary artery," Journal of Ethnopharmacology, vol. 269, 2021.

[26] X. X. Dou, S. Lin, X. H. Tian et al., "Systematic characterization of the chemical constituents in vitro and prototypes in vivo of Dingkun Dan by UPLC-Q-TOF/MSE combined with the UNIFITM software," Biomedical Chromatography, vol. 8, 2020.

[27] T. Herraiz, H. Guillén, V. J. Arán, and A. Salgado, "Identification, occurrence and activity of quinazoline alkaloids in Peganum harmala," Food and Chemical Toxicology, vol. 103, pp. 261-269, 2017.

[28] H. S. Da Rosa, I. S. Coelho, M. D. da Silva et al., "Sida tuberculata extract reduces the nociceptive response by chemical noxious stimuli in mice: implications for mechanism of action, relation to chemical composition and molecular docking," Phytotherapy Research, vol. 33, no. 1, pp. 224-233, 2019.

[29] K. R. Markham, "Ultraviolet-visible absorption spectroscopy," in Techniques of Flavonoid Identification, K. R. Markham, Ed., pp. 36-51, Academic Press, London, UK, 1982.

[30] Y. Shao, J. Jiang, L. Ran, C. Lu, C. Wei, and Y. Wang, "Analysis of flavonoids and hydroxycinnamic acid derivatives in rapeseeds (Brassica napusL. var.napus) by HPLC-PDA-ESI(-)-MSn/
HRMS," Journal of Agricultural and Food Chemistry, vol. 62, no. 13, pp. 2935-2945, 2014.

[31] N. Akhtar, V. M. Thadhani, F. Ul Haq, M. N. Khan, S. Ali, and S. G. Musharraf, "Rapid identification and quantification of bioactive metabolites in processed Camellia sinensis samples by UHPLC-ESI-MS/MS and evaluation of their antioxidant activity," Journal of Industrial and Engineering Chemistry, vol. 90, pp. 419-426, 2020.

[32] P. M. Kearney, M. Whelton, K. Reynolds, P. Muntner, P. K. Whelton, and J. He, "Global burden of hypertension: analysis of worldwide data," The Lancet, vol. 365, no. 9455, pp. 217-223, 2005.

[33] P. K. Mukherjee and A. Wahile, "Integrated approaches towards drug development from Ayurveda and other Indian system of medicines," Journal of Ethnopharmacology, vol. 103, no. 1, pp. 25-35, 2006.

[34] K. B. Tibazarwa and A. A. Damasceno, "Hypertension in developing countries," Canadian Journal of Cardiology, vol. 30, no. 5, pp. 527-533, 2014.

[35] M. Heinrich, S. Edwards, D. E. Moerman, and M. Leonti, "Ethnopharmacological field studies: a critical assessment of their conceptual basis and methods," Journal of Ethnopharmacology, vol. 124, no. 1, pp. 1-17, 2009.

[36] F. Visioli, "Nutritional support in the pharmacological treatment of metabolic syndrome," European Journal of Pharmacology, vol. 668, pp. S43-S49, 2011.

[37] M. Bucci, J.-P. Gratton, R. D. Rudic et al., "In vivo delivery of the caveolin-1 scaffolding domain inhibits nitric oxide synthesis and reduces inflammation," Nature Medicine, vol. 6, no. 12 , pp. 1362-1367, 2000.

[38] S. Moncada and E. A. Higgs, "The discovery of nitric oxide and its role in vascular biology," British Journal of Pharmacology, vol. 147, no. S1, pp. S193-S201, 2006.

[39] P. Tangsucharit, S. Takatori, Y. Zamami et al., "Muscarinic acetylcholine receptor M1 and M3 subtypes mediate acetylcholine-induced endothelium-independent vasodilatation in rat mesenteric arteries," Journal of Pharmacological Sciences, vol. 130, no. 1, pp. 24-32, 2016.

[40] J. Tamargo, J. Segura, and L. M. Ruilope, "Diuretics in the treatment of hypertension. Part 2: loop diuretics and potassium-sparing agents," Expert Opinion on Pharmacotherapy, vol. 15, no. 5, pp. 605-621, 2014.

[41] F. A. Lívero, J. V. Menetrier, E. L. Botelho Lourenco, and A. Gasparotto, "Cellular and molecular mechanisms of diuretic plants: an overview," Current Pharmaceutical Design, vol. 23, no. 8, pp. 1247-1252, 2017.

[42] L. C. Garg, "Actions of adrenergic and cholinergic drugs on renal tubular cells," Pharmacological Reviews, vol. 44, no. 1, pp. 81-102, 1992.

[43] M. Jun, V. Venkataraman, M. Razavian et al., "Antioxidants for chronic kidney disease," The Cochrane Database of Systematic Reviews, vol. 10, Article ID CD008176, 2012.

[44] P. Waffo-Teguo, D. Lee, M. Cuendet, J.-M. Mérillon, J. M. Pezzuto, and A. D. Kinghorn, "Two new stilbene dimer glucosides from grape (vitisvinifera) cell cultures," Journal of Natural Products, vol. 64, no. 1, pp. 136-138, 2001.

[45] X. Yu, M. Zhao, F. Liu, S. Zeng, and J. Hu, "Identification of 2,3-dihydro-3,5-dihydroxy-6-methyl-4H-pyran-4-one as a strong antioxidant in glucose-histidine Maillard reaction products," Food Research International, vol. 51, no. 1, pp. 397-403, 2013.

[46] S. JuŸwiak, J. Wójcicki, K. Mokrzycki et al., "Effect of quercetin on experimental hyperlipidemia and atherosclerosis 
in rabbits," Pharmacological Reports, vol. 57, no. 57, pp. 604-609, 2005.

[47] N. Kamalakkannan and P. S. M. Prince, "Antihyperglycaemic and antioxidant effect of rutin, a polyphenolic flavonoid, in streptozotocin-induced diabetic wistar rats," Basic Clinical Pharmacology Toxicology, vol. 98, no. 1, pp. 97-103, 2006.

[48] S. Godse, M. Mohan, V. Kasture, and S. Kasture, "Effect of myricetin on blood pressure and metabolic alterations in fructose hypertensive rats," Pharmaceutical Biology, vol. 48, no. 5, pp. 494-498, 2010.

[49] K. Zhang, W. Song, D. Li, and X. Jin, "Apigenin in the regulation of cholesterol metabolism and protection of blood vessels," Experimental and Therapeutic Medicine, vol. 13, no. 5, pp. 1719-1724, 2017.

[50] W. Younis, Alamgeer, V. B. Schini-Kerth et al., "Role of the NO/cGMP pathway and renin-angiotensin system in the hypotensive and diuretic effects of aqueous soluble fraction from Crataegus songarica K. Koch," Journal of Ethnopharmacology, vol. 249, p. 112400, 2020. 